This is an Open Access version of the aricle: Vanmaercke M, Obreja F, Poesen J (2014) Seismic controls on contemporary sediment export in the Siret river catchment, Romania. Geomorphology 216: 247-262. DOI: 10.1016/j.geomorph.2014.04.008

\title{
Seismic controls on contemporary sediment export in the Siret river catchment, Romania
}

\author{
Matthias Vanmaercke ${ }^{\mathrm{a}, \mathrm{b}}$, Florin Obreja ${ }^{\mathrm{c}, \mathrm{d}}$, Jean Poesen ${ }^{\mathrm{a}}$ \\ ${ }^{a}$ Department of Earth and Environmental Sciences, KU Leuven, Heverlee, Belgium \\ ${ }^{\mathrm{b}}$ Research Foundation Flanders (FWO), Brussels, Belgium \\ c Department of Geography, "Stefan cel Mare" University of Suceava, Romania \\ ${ }^{\mathrm{d}}$ River Forecast, Hydrology and Hydrogeology Bureau of The SIRET Water Branch, Bacau, Romania
}

\begin{abstract}
While differences in catchment sediment yield $\left(S Y,\left[\mathrm{t} \mathrm{km}^{-2} \mathrm{y}^{-1}\right]\right)$ are generally attributed to topography, lithology, climate and land use, recent studies have highlighted that also seismic activity may have an important impact on $S Y$. Nonetheless, relatively little is known about the importance of this factor and the processes and mechanisms explaining its influence. Therefore, this study explores the role of seismic activity in explaining spatial and temporal variation in sediment export within the Siret Basin (Romania, $45000 \mathrm{~km}^{2}$ ), a catchment with a large variability in seismic activity.

Based on previously unpublished long-term (> 30 years) SY measurements for 38 subcatchments of the Siret, we analyze the correlation between average $S Y$, seismic activity and various other catchment characteristics. Our results showed that spatial variation in average $S Y$ was indeed strongly correlated with the degree of seismic activity in each catchment $\left(R^{2}=0.74\right)$. Also catchment lithology explained an important part of the differences in $S Y\left(R^{2}=0.67\right)$. The combination of these two factors accounted for about $80 \%$ of the observed variation in $S Y$, while other factors (e.g. topography, land use, climate, and runoff) did not significantly contribute to the explained variance in average $S Y$.

To explore the impact of a specific earthquake event on sediment export, we analyzed daily variations in suspended sediment concentrations of 10 subcatchments, five years before and after an earthquake of $M w=7.4$ that affected the Vrancea region in 1977 and triggered a substantial number of landslides. Only one catchment showed a clear (3-fold) increase in
\end{abstract}


sediment concentrations at unit discharge. For the other nine catchments, no consistent increase could be observed. This indicates that the impact of seismic activity on average $S Y$ is mainly indirect and not associated with sudden pulses of sediments, caused by earthquaketriggered landslides. Potential mechanisms that could explain such indirect responses are discussed.

Keywords: Sediment Yield; Lithology; Seismic activity; Earthquake-triggered landslides; Event efficiency index; Sediment rating curve

\section{Introduction}

Predicting sediment export by rivers is important for economical, ecological and geomorphic reasons (e.g. Owens et al., 2005; Syvitski and Milliman, 2007). However, the factors that control export rates are not yet fully understood. Hence predictions of sediment export at catchment scale are mainly based on empirical relations between measured sediment export rates and factors describing the topography, lithology, land use and climatic characteristics of catchments (e.g. Merrit et al., 2003; de Vente and Poesen, 2005; de Vente et al., 2013). Tectonic activity is generally not accounted for by these models, as it is (often implicitly) expected that eventual effects of tectonic activity on erosion and sediment fluxes are sufficiently represented by the topography of catchment (e.g. Milliman and Syvitski, 1992; de Vente and Poesen, 2005; Syvitski and Milliman, 2007; de Vente et al., 2013).

A growing number of studies show that this assumption is not always justified. Spatial variation in both long-term erosion rates (Portenga and Bierman, 2011) and contemporary catchment sediment yields $\left(S Y,\left[\mathrm{t} \mathrm{km}^{-2} \mathrm{y}^{-1}\right]\right)$ are often strongly correlated with the degree of seismic activity within the catchments, even in regions with a relatively limited degree of seismic activity (Dadson et al., 2003; Vanmaercke et al., in press). Also after correcting for auto-correlations between topography, seismic activity remains a significant predictor of erosion rates or SY (Portenga and Bierman, 2011; Vanmaercke et al., in press). Several mechanisms may explain this effect. Earthquakes may trigger landslides, resulting in a direct increase in sediment export (e.g. Keefer, 2002; Dadson et al., 2004; Hovius et al., 2011). Secondly, seismic activity may cause rock fractures, leading to an increased susceptibility to erosion (e.g. Molnar et al., 2007; Koons et al., 2012). Furthermore, the occurrence of earthquakes is often correlated with tectonic uplift, which may result in river incision and hence increased sediment output at the catchment scale (e.g. Whittaker et al., 2010; Larsen and Montgomery, 2012). 
The relative importance of these different mechanisms and the overall importance of seismic activity for $S Y$ in general is currently poorly understood. Our insight in these matters can be improved by detailed studies on the relationship between seismic activity and sediment export. However, few such studies are currently available and either provide only a regional analysis of the relationship between seismic activity and average SY (e.g. Portenga and Bierman, 2011; Vanmaercke et al., in press) or focus only on catchments with an exceptionally high degree of seismic activity and large relief (i.e. mainly in Taiwan; e.g. Dadson et al., 2003, 2004; Hovius et al., 2011; Huang and Montgomery, 2012).

In a recent study, Hovius et al. (2011) explored the effects of the $M w$ 7.6 Chi-Chi earthquake in Taiwan on the sediment export by rivers near the epicentre. They observed that the period after the earthquake was followed by a period of enhanced mass wasting and fluvial sediment evacuation. Sediment export peaked to more than five times the background rate but returned progressively to pre-earthquake levels in about six years (Hovius et al., 2011). However, Huang and Montgomery (2012) argued that it is very difficult to unambiguously relate these increases in sediment export to earthquake-triggered landslides, as also the occurrence of typhoons or extreme rainfall events may provide a plausible explanation. They further suggest that the earthquake had only a relatively limited impact on $S Y$ of their studied catchment. Higher sediment concentrations were only observed during low-flow events but not during higher flows (Huang and Montgomery, 2012). Studies exploring the effects of earthquake on temporal changes in $S Y$ for other regions are currently lacking.

This study therefore aims to better comprehend the relationship between seismic activity and $S Y$ and the mechanisms behind this relationship. This is done by investigating factors controlling $S Y$ and the evolution of sediment export for catchments with different degrees of seismic activity in and near the Vrancea region (Romania). The specific objectives are: (i) to analyse the spatial correlation between average catchment $S Y$ and seismic activity for catchments in and near the Vrancea region; and (ii) to evaluate the potential effect of a large $(M w=7.4)$ earthquake on the temporal variation of sediment export for a number of catchments at varying distances from the epicentre.

\section{Study area}

This study focuses on subcatchments of the Siret river (45000 km²; Fig. 1), which drains the central and eastern part of the Eastern Carpathians, Eastern Sub-Carpathians, Moldavian Plateau and The Siret Lower Plain. The study area is part of the Alpine-Carpathian orogenic belt, resulting from the convergence and collision of several micro-plates (Moesian-Valachian 
micro-plate, Black Sea micro-plate, Inner Carpathian micro-plate) with the Eurasian plate during the closure of the Tethys Ocean (Airinei, 1977). The geological structures of this region are the result of the subduction process of the East-European plate (Eurasian plate), Moesian-Valachian micro-plate and Black Sea micro-plate under the Inner Carpathian microplate (Airinei, 1977; Sandulescu, 1984). After the Miocene, the subduction of the tectonic plates mentioned above stopped, and only the Black Sea micro-plate continued to advance under the Carpathians, being currently responsible for the tectonic activity in the SouthEastern Carpathians (Radu, 1965; Sandulescu, 1984).

Part of the Siret basin (the 'Vrancea region') is still characterized by important neo-tectonic movements (Sandulescu, 1984) and is one of the most seismically active regions of Europe (Balan et. al., 1982; Constantinescu and Enescu, 1985; Shedlock et al., 2000). During the last decades, several major earthquakes have occurred in this region (Table 1). The mountainous areas of this region are subjected to considerable uplift (2-4 $\mathrm{mm} \mathrm{y}^{-1}$; Balan et. al., 1982), while the lower plains of the Siret, located at the confluence with the Danube, are affected by subduction (Fig. 1; Săndulescu, 1984). Also the west part of the Vrancea region, the Barsei depression, is affected by subduction. (--2 to $-4 \mathrm{~mm} \mathrm{yr}^{-1}$; Airinei, 1977) and has been subjected to several major earthquakes with a high toll of casualties and damage. The epicenters of most of the earthquakes are confined to a relatively small region of $40 \times 80 \mathrm{~km}$ (Fig. 1) and are located at a depth of 60 to $180 \mathrm{~km}$ (Oncescu and Bonjer, 1997).

The Siret catchment is characterized by several lithological units (Fig. 1), ranging from volcanic, crystalline and flysch mountains to Molasses (marls, gypsum, salt, clay shists, and conglomerates) and Quaternary sediments (marls, clay, sands, loess, sandstones, and limestones) in the Sub-Carpathians, plateaus and lowland areas (Mutihac and Ionesi, 1974; Mutihac et al., 2004). Overall, relief within the catchment decreases from west to east and from north to south. Altitude ranges between ca. 10 and $2100 \mathrm{~m}$ a.s.l. Land use in the Siret catchment is mixed. Agriculture is mainly practiced on the plateaus and in the lowland areas with a lithology of Molasse or Quaternary sediments. The more mountainous areas with flysch, volcanic and crystaline rocks are mainly forested.

The climate of the catchment can be described as temperate continental. Mean annual precipitation in the catchment varies between 650 and $1000 \mathrm{~mm}$ in the mountainous areas and 380 and $600 \mathrm{~mm}$ in the plateau and lowland areas (Sandu et al., 2008). However, average precipitation is susceptible to very large inter-annual variability. This is reflected in the river discharges, with prolonged periods of low runoff and the occurrence of large floods (e.g. in 2004, 2005, 2008 and 2010). Rainfall and runoff discharges are also characterized by 
important seasonal variations: the largest flood events generally occur during the summer season (June-August) due to torrential rain. Also in spring, significant flood events may occur as a result of snow melt in combination with heavy rainfall. However, these floods are generally smaller than the summer floods (Diaconu et al., 1970; Podani and Zăvoianu, 1992; Diaconu and Şerban, 1994; Mustăţea, 2005; Rădoane et al., 2007; Olariu et al., 2009; Obreja, 2012).

\section{Materials and methods}

\subsection{Selection of the subcatchments and sediment yield measuring procedure}

In this study, 38 subcatchments of the Siret basin were selected for which measured suspended sediment export data were available (Table 2; Fig. 1). Data from these 38 catchments were used because it was known that their runoff and sediment discharge were not significantly affected by reservoirs in their upstream area and because they were monitored practically at a daily basis for at least 30 years. The latter criterion was considered because earlier studies showed that the reliability of $S Y$ measurements strongly depends on the measurement frequency and length (e.g. Phillips et al., 1999; Moatar et al., 2006; Vanmaercke et al., 2012). Hydrological and sediment export measurements were conducted by the Siret River Water Branch and Buzau-Ialomita Water Branch from the "Romanian Water" National Administration, and retrieved from their databases. For 33 of the considered catchments (1-

33 , see Table 2), daily average runoff discharges $\left(Q,\left[\mathrm{~m}^{3} \mathrm{~s}^{-1}\right]\right)$, and suspended sediment concentration (SSC, $\left.\left[\mathrm{g} \mathrm{l}^{-1}\right]\right)$ data were available. For the five remaining catchments (34-38, see Table 2) only the long-term average runoff depth (Ro, $\left.\left[\mathrm{mm} \mathrm{y}^{-1}\right]\right)$ and $S Y$ values were available to the authors.

For each catchment, $Q$ was based on two runoff discharge observations per day. SSC was measured at a flow proportional basis: at least four suspended sediment samples per month were taken, while additional samples were taken every day that $Q$ exceeded 1.25 times the long-term average discharge. During large flood events, SSC samples were often taken at an hourly basis. For days during which no $S S C$-samples were taken, SSC was estimated by a linear time-based interpolation of the preceding and following measured SSC values during low runoff discharges. Overall these interpolations are of little importance for the total sediment export: less than $20 \%$ of the total sediment export occurs during these low flow discharges (Diaconu, 1971; Diaconu and Şerban, 1994; Rădoane et al., 2007; Olariu et al., 2009; Obreja, 2012). Average $S Y$ values were obtained by calculating the sediment export on a daily basis and integrating all daily values over the whole measuring period (Table 2). 
Details on the measuring procedure can be found in Diaconu and Lăzărescu (1965) and NIHWM (1997).

\subsection{Analyzing the spatial variability of sediment yield}

To address the first objective of this study, several catchment characteristics were determined for each catchment, describing the size, climatic conditions, topography, lithology, land use and degree of seismic activity. Most of these variables were also used in previous studies trying to identify factors controlling $S Y$ (e.g. Montgomery and Brandon, 2002; Syvitski and Milliman, 2007; de Vente et al., 2011; Vanmaercke et al., in press). An overview of these parameters is given in Table 3, whereas their values for each catchment are listed in Tables 2 and 4.

Based on these data, the potential importance of catchment size, climate, topography, lithology, land use and seismicity in explaining the spatial variation in average SY was explored by means of correlation analysis. To account for potential inter-correlations between these variables, partial correlation analyses were also conducted. Partial correlation measures the degree of association between two variables, with the effect of other controlling variables removed (Fisher, 1924; Steel and Torrie, 1960). Assume that we calculate the partial correlation between variables $A$ and $B$, after controlling for another variable, $C$. The partial correlation is then calculated by calculating the correlation between the residue of a regression between $A$ and $C$ and that between $B$ and $C$. These residues represent the variation in $A$ and $B$ that cannot be attributable to $C$ (Fisher, 1924; Steel and Torrie, 1960; Vanmaercke et al., in press).

To account for the order of magnitude variation in SY (Table 2), correlation and partial correlation analyses were conducted on the logarithmically transformed $S Y$ values. This is a commonly used strategy for identifying factors controlling SY (e.g. Aalto et al., 2006; de Vente et al., 2011; Vanmaercke et al., in press). Likewise, most of the considered catchment characteristics were logarithmically transformed and both the normal and log-transformed values were considered in the (partial) correlation analyses.

\subsection{Temporal variation in sediment export}

To assess the potential effect of a large earthquake on the sediment export of river systems (i.e. the second objective of this study), we analyzed the temporal variation in sediment export before and after the 1977 earthquake $(M w=7.4$, see Table 1) for ten of the 33 gauging stations described in Section 3.1. The 1977 earthquake was considered because it was the 
strongest earthquake during the period of sediment export measurements. It is also known that this earthquake triggered a large number of landslides (Bălteanu, 1979). Moreover, a sufficiently large number of runoff events occured in the studied catchments during the five years after this earthquake event. This allowed exploring the impact of this earthquake on sediment export under a sufficiently large range of runoff conditions. The other two major earthquakes (i.e. in 1986 and 1990; see Table 1) occured during very dry periods. Very few significant runoff events (i.e. with a runoff discharge exceeding 1.25 times the long-term average runoff discharge and SSC being measured; see Section 3.1) occurred the years following these earthquakes. Moreover, no information about the occurence of landslides associated with these earthquakes was available.

The 10 selected catchments (i.e. Ciuruc, Tulnici, Jilişte, Tulburea, Nereju, Goleşti, Valea Uzului, Ferăstrău, Brodina and Dragoşa) are comparable in terms of lithology (mainly Flysch and Molasse) and are generally relatively well forested (Table 4; Fig. 1). Average distances of these catchments to the epicenter of the 1977 earthquake range between $16 \mathrm{~km}$ (Goleşti) and $258 \mathrm{~km}$ (Brodina).

Assessing the effect of an earthquake on the temporal variation in sediment export requires that also variations in sediment export due to climatic variability (i.e. fluctuations in runoff discharge) are taken into account. Hovius et al. (2011) did this by comparing sediment rating curves before and after the 7.6 Mw Chi-Chi earthquake. A sediment rating curve describes the relationship between the runoff discharge at a given moment $(Q)$ and the corresponding suspended sediment concentration (SSC):

$$
S S C=\mathrm{a} Q^{\mathrm{b}}
$$

where $a$ and $b$ are the fitted coefficient and exponent of the rating curve. One can expect that overall changes in sediment supply and transport that are not due to short-term variations in runoff discharge will be reflected as differences in these fitted values for rating curves based on observations made before and after the considered earthquake (Asselman, 2000; Vanmaercke et al., 2010; Hovius et al., 2011)

In this study, a similar approach was followed. For each of the ten selected gauging stations, rating curves in the form of Eq. (1) were fitted based on all available daily $Q$ and SSC values up to five years before the earthquake. These rating curves were then compared with that based on $Q$ and SSC data collected during the five years after the earthquake. We used two strategies to fit the curves. First, both the coefficient and exponent of the rating curve were 
fitted to the observations. Alternatively, we also fitted the equations by using the same $b$ exponent as that obtained for the five years before the earthquake and then only adapting the $a$ coefficient. This approach was also followed by Hovius et al. (2011). All rating curves were fitted using a non-linear regression procedure, as earlier studies demonstrated that this is most likely the best procedure to obtain unbiased estimates of SSC (Asselman, 2000; Vanmaercke et al., 2010). The predictive power of each rating curve was assessed by means of the Nash and Sutcliffe model efficiency (ME; Nash and Sutcliffe, 1970).

A potential problem with the comparison of rating curves is that these equations may be strongly controlled by a few observations with a very high $Q$ and/or SSC (e.g. Walling, 1977; Phillips et al., 1999; Vanmaercke et al., 2010). To account for this, the potential impact of the 1977 earthquake on sediment transport was also evaluated by means of the event efficiency index (EEI). EEI was proposed by Steegen et al. (2000) and successfully used in other studies aiming to study temporal variation in sediment export (e.g. Vanmaercke et al., 2010). Similar to the rating curves, EEI compensates for the fact that variations in SSC are partly controlled by changes in runoff discharge (Steegen et al., 2000):

$$
E E I=S S C / Q
$$

Using this formula, we calculated EEI for each significant runoff event for which SSC samples were taken (see section 3.1). For every selected gauging station, the distribution of $E E I$ values from all events up to five years before the earthquake was compared with the EEI distributions of measured events following the first 1,2 and 5 years after the earthquake. The significance of observed differences was evaluated by means of the non-parametric Wilcoxon test (Wilcoxon, 1945).

\section{Results}

\subsection{Spatial variation in sediment yield}

Table 5 lists the Pearson correlation coefficients ( $r$ ) between $S Y$ (Table 2) and all the considered catchment characteristics (Table 4). Of all these variables, $P G A$ shows the strongest correlation with the natural logarithm (ln) of SY (Fig. 2a). Likewise, the other measures of seismic activity ( $E D$ and $C M D$ ) show somewhat weaker but clearly significant correlations with $\ln (S Y)$. Catchment lithology, expressed by the $L$ factor, also correlates strongly with $S Y$ (Table 5, Fig. 2b). Surprisingly, the average annual runoff depth shows a negative correlation with $S Y$ (Table 5, Fig. 2c). This is also the case for the mean local relief 
of the catchments and the average catchment slope (Table 5, Fig. 2d). Regarding land use the fraction of arable land shows a significantly positive correlation with $S Y$ (Fig. 2e) whereas the fraction of forest cover shows an insignificant correlation (Table 5). Catchment area showed no significant correlations with $S Y$ (Fig. 2f).

Several of the considered catchment characteristics also correlate with each other (Table 5). For example, $P G A$ shows a negative correlation with $M L R$ and average catchment slope. The calculated $L$ factor value shows a negative correlation with topography and the average runoff depth, but a strong positive correlation with $P G A$ and the fraction of arable land. These intercorrelations make it difficult to clearly identify the controlling factors of SY. However, a better insight in their importance could be obtained from the partial correlation analyses. These analyses showed that $P G A$ remains significantly $(\alpha=0.05)$ partially correlated with $\ln (S Y)$ after controlling for any variable related to topography, lithology, land use, runoff or climate. Likewise $\ln (L)$ remained significantly partially correlated with $\ln (S Y)$ after controlling for any factor describing the seismic activity, topography, land use, runoff or climate of the catchments. After controlling for both seismic activity (PGA) and lithology $(L)$ no other considered variables showed a significant partial correlation with $\ln (S Y)$. Based on this information, a multiple regression model was fitted that predicts $S Y$ based on the $L$ score and $P G A$ value of the catchment:

$$
S Y_{\text {pred }}=72.1 \times e^{0.68 P G A} \times L^{0.93}\left(n=38, R^{2}=0.80\right)
$$

This model explains about $80 \%$ of the observed variation in $\ln (S Y)$. All predicted values deviate less than a factor 4 from their actual observed $S Y$-value, whereas $84 \%$ (32 out of 38 predicted values) deviate less than a factor 2 from their corresponding observed $S Y$ value (Fig. $3)$.

\subsection{Temporal variation in sediment export}

Table 6 lists the results of the fitted rating curve equations (Eq. 1) and their corresponding $M E$ values, while Fig. 4 gives a graphical overview of the fitted coefficient a and exponent $b$ values. These results show that, although several of the rating curves based on observations after the 1977 earthquake have a higher a or $b$ values than the corresponding rating curve before the earthquake, these changes are certainly not systematic present at all stations and for all time periods. An increase in the coefficient a is also often compensated for by a decrease in the exponent $b$ and vice versa. Rating curves using the same exponent as before the 
earthquake have a somewhat lower $M E$. However, this decrease in predictive power is generally very small (Table 6). Also these rating curves with a fixed exponent do not systematically show higher a values after the earthquake (Fig. 4). This is further illustrated for two stations in Fig. 5. At Nereju, SSC observations for a given $Q$ made two years after the earthquake are generally higher than observations made five years before the earthquake. This is mainly reflected in a larger exponent $b$ of the rating curve (Table 6). When the exponent $b$ is kept constant, this results in a ca. threefold increase in the coefficient a. At Tulnici, on the other hand, the rating curve based on $Q$ and $S S C$ observations made two years after the earthquake is almost identical to the rating curve based on observations made before the earthquake.

Fig. 6 shows the variability of the coefficient a of rating curves with a fixed exponent, derived from all observations made in the five years before the earthquake (Table 6) based only on the $Q$ and SSC data of the indicated year. Hence, this graph indicates the intrinsic year-to-year variability in the relationship between runoff discharge and sediment concentrations. When this variability is considered, only the Nereju catchments seem to show a clear (3-fold) increase in the coefficient a after the earthquake. For the other catchments, no consistent increase after the earthquake can be detected.

The results obtained from analyzing EEI (Eq. 2) during important flood events are also not consistent for all stations (Fig. 7). EEI for flood events monitored during the first year after the earthquake are significantly larger than those before the earthquake for five out of the 10 stations. Three other stations show an insignificant increase, whereas two show a significant decrease in EEI (Fig. 7). When a period of two years after the earthquake is considered, five of the stations show a significant increase and one a significant decrease. After five years, four stations show a significant increase in EEI whereas as many show a significant decrease (Fig. 7).

\section{Discussion}

\subsection{Factors controlling spatial variation in average catchment sediment yield}

The results of our partial correlation analyses showed that spatial differences in $S Y$ are mainly explained by differences in seismic activity (expressed as $P G A$ ) and lithology (expressed as $L$ ) between the catchments (Table 5, Fig. 2). The importance of lithology in explaining differences in SY is well known (e.g. Bruijnzeel, 2004; Rădoane and Rădoane, 2005; de Vente et al., 2006; Aalto et al., 2006; Syvitski and Milliman, 2007), whereas also a growing number 
of studies illustrate that seismic activity may have a significant control on spatial variation in SY (e.g. Dadson et al., 2003; Portenga and Bierman, 2011; Vanmaercke et al., in press). Nonetheless, the fact that these two factors alone explain ca. $80 \%$ of the observed variation in mean annual $S Y$ for the 38 studied catchments in the Siret basin can be considered surprising (Fig. 3). For example, land cover is also commonly reported to have an important control on SY or long term erosion rates (e.g. Vanacker et al., 2007; Portenga and Bierman, 2011; NadalRomero et al., 2011). Also for the considered subcatchments of the Siret basin, a significant exponential relationship between the fraction of Arable Land (AL) and $S Y$ was noted (Fig. 2e). However, once correcting for the inter-correlation between $L$ and $A L$ (Table 5), the partial correlation between $A L$ and $S Y$ became insignificant.

It should be noted that this does not necessarily mean that land use is of no importance for sediment fluxes in the Siret basin. Firstly, the catchment number (38) is fairly low and most likely insufficient to statistically differentiate the control of land use from the control of lithology on $S Y$. The fact that $L$ shows a much better correlation with $S Y$ (Fig. 2b) than $A L$ (Fig. 2e) indicates that lithology is more important for explaining differences in $S Y$ than land use. However, this strong correlation between $L$ and $S Y$ is most likely partly attributable to the fact that catchments with erodible lithologies are also cultivated more intensely, whereas catchments on hard volcanic and crystalline rocks are mainly forested. Secondly, whereas the land cover data used in this study are representative for 1990 (EEA, 2010), the average $S Y$ values used for this period generally cover a much longer time period (Table 2). Since the 1950s important land use changes have occurred in the Siret basin including both reforestation and deforestation (Rădoane et al., 2013). For example, a comparison between the CORINE land cover data for subcatchments of the Siret basin indicated a decrease in forest cover up to 5\% between 1990 and 2006 (Rădoane et al., 2013). As a result, the land cover data used in this study are not entirely representative for the land use corresponding to the average $S Y$ values. A more detailed temporal analysis of changes in land cover and sediment fluxes would probably indicate a significant impact of land use on $S Y$. However, no historical land use data were available that could allow such analyses. Nonetheless, our results indicate that land use is only of secondary importance in explaining spatial variability in $S Y$. This corresponds with findings of other studies indicating that that land use changes have only a modulating impact on river bed morphology of several Romanian rivers (e.g. Rădoane et al., 2003, 2010, 2013; Perşoiu and Rădoane, 2011).

Also the river discharge is commonly expected to exert a control on SY (e.g. Syvitski and Milliman, 2007), whereas in this study a counter-intuitive negative trend between the average 
annual runoff depth (Ro) and $S Y$ was observed (Fig. 2c). This correlation became insignificant after controlling for lithology, which shows a strong positive correlation with $S Y$ and a negative correlation with $R o$ (Table 5). A lack of correlation between $S Y$ and runoff or precipitation depth was also reported in several earlier studies (e.g. Aalto et al., 2006; de Vente et al., 2011) and might be explained by the fact that often not the total average annual rainfall or runoff depth but the magnitude and frequency of floods have an important impact on $S Y$ (e.g. Markus and Demissie 2006; Alexandrov et al., 2007; Vanmaercke et al., 2010). To further investigate the importance of floods for the studied catchments, we analyzed the relationship between $S Y$ and the total percentage of runoff discharge that occurs during the largest floods, i.e. the highest $2 \%$ of all daily runoff observations $\left(V_{\mathrm{W} 2},[\%]\right)$. This measure was also used in other studies focusing on the relationship between the occurrence of floods and sediment export (e.g. Moatar et al., 2006; Raymond et al., 2013). $V \mathrm{w}_{2}$ was calculated for the 33 catchments with daily runoff and sediment discharge observations available to the authors (see Section 3.1) and showed indeed a strong correlation with mean annual SY (Fig. 8). This indicates that the occurrence of floods may indeed have a significant impact on annual $S Y$. However, $V_{\mathrm{W} 2}$ also shows clear correlations with catchment lithology: the highest $V_{\mathrm{W} 2}$ values are observed in catchments with an erodible lithology of molasse or platform and Quaternary sediments, whereas catchments with a volcanic and crystalline lithology generally have a much lower $V_{\mathrm{W} 2}$ (Fig. 8). After correcting for lithology $(L), V_{\mathrm{W} 2}$ no longer showed a significant correlation with $S Y$ (partial $r=0.24, p=0.1866, n=33$ ). It is therefore most likely that the strong correlation observed in Fig. 8 can be partly attributed to differences in lithology. Likewise, the strong correlation between $L$ and $S Y$ (Fig. 2b) is probably partly due to the fact that catchments with more erodible lithologies are also more susceptible to flood events. In this context, it is important to point out that the occurrence of floods most likely has little impact on the observed correlation between seismicity and $S Y$. After correcting for both $V_{\mathrm{W} 2}$ and $L, P G A$ and $\ln (S Y)$ remain significantly correlated (partial $r=0.57, p=0.0008, n=$ 33). Likewise, $V_{\mathrm{W} 2}$ remains significantly correlated with $\ln (S Y)$ after correcting for $P G A$ (partial $r=0.47, p=0.0071, n=33$ ).

Many studies have illustrated the importance of topography in explaining spatial differences in $S Y$ and long-term erosion rates (e.g. Milliman and Syvitski, 1992; Montgomery and Brandon, 2002; Syvitski and Milliman, 2007). However, surprisingly, none of the considered topographic variables showed a meaningful correlation with $S Y$. Both the average catchment slope and Mean Local Relief (MLR) show negative correlations with $L$ and PGA (Table 5), explaining their negative correlation with $S Y$ (Fig. 2d). After controlling for $L$ and $P G A$, these 
measures no longer show a significant correlation with $S Y$. This lack of correlation may be partly attributed to the fairly low number of observations in these analyses (38 catchments), the fact that only spatially lumped topographic factors were considered and the relatively narrow range of topographic conditions of the studied catchments (Table 4) compared to global or continental-wide studies. Nonetheless, the considered topographic variables concur with those used in earlier studies reporting a strong topographic control on $S Y$ (e.g. Milliman and Syvitski, 1992; Montgomery and Brandon, 2002; Syvitski and Milliman, 2007; de Vente et al., 2011; Vanmaercke et al., in press), whereas the topographic differences between the studied catchments are also far from neglectable. MLR values range between 242 and $753 \mathrm{~m}$ (Table 4), i.e. about $25 \%$ of the variation in MLR that occurs at a global scale (Montgomery and Brandon, 2002). Our results therefore illustrate that the impacts of tectonic activity such as earthquakes and uplift on erosion rates, and sediment fluxes are not always reflected in the overall catchment topography and may even counteract the impact of topography on these fluxes. This finding concurs with those of several studies (e.g. Montgomery and Brandon, 2002; DiBiasi et al., 2010; Portenga and Bierman, 2011; Vanmaercke et al., in press) and imply that tectonic activity should be explicitly considered when explaining spatial differences in $S Y$ or long-term erosion rates.

\subsection{Impact of climate and earthquakes on temporal variability in sediment export}

Although our analyses show that seismic activity has a clear and significant impact on the spatial variability of average $S Y$, our analyses of the temporal variability of sediment concentrations generally do not reveal an impact of the 1977 earthquake. Whereas for some catchments an increase in rating curve parameters (Table 6, Fig. 5) or EEI (Fig. 7) could be observed in the years following this earthquake, other catchments showed no such increase or even a decrease. Moreover, the observed increases are often only small and might also be attributed to the intrinsic variability of the relationship between runoff discharge and sediment concentration (Fig. 6).

When this variability is taken into account, most of the considered catchments do not show a convincing response to the 1977 earthquake in terms of sediment export. Only for the Nereju catchment, a clear and consistent threefold increase in the coefficient a can be observed after the 1977 earthquake (Figs. 4, 5 and 6). Also in terms of EEI, Nereju showed a consistent and significant increase compared to the five years before the earthquake (Fig. 7). This catchment was located very close to epicenter of the earthquake (Fig. 1). Since damage reports indicate that the impacts of the 1977 earthquake mainly occurred south of the epicenter (Oncescu and 
Bonjer, 1997), Nereju was probably the catchment with the largest ground acceleration due to the earthquake. It is therefore likely that the observed increases in rating curve coefficients and EEI for this catchment are indeed due to the 1977 earthquake.

It should be noted that, whereas both the method of comparing fitted rating curve parameters and comparing EEI values (Section 3.3) to correct (to some extent) for the fact that variability in SSC is partly controlled by variability in runoff discharge, these methods cannot provide a full correction because day to day variability in $S S C$ is often very high and related to specific weather and catchment conditions (e.g. Asselman, 2000; Vanmaercke et al., 2010). For example, part of the variability in EEI or fitted rating curve parameters might be attributed to differences in timing and magnitude of specific runoff events. Differences in flood magnitude are also indicated by the fact that the contribution of large runoff events to the annual runoff discharge, expressed as the $V_{\mathrm{W} 2}$, clearly varies between the considered periods (Table 6). Nonetheless, differences in $V_{\mathrm{W} 2}$ did not directly explain the observed differences in $E E I$ or rating curve coefficients before and after the earthquake. In this context, it may also be argued that the 1977 earthquake caused only a short but significant increase in sediment export directly after the earthquake and that this increase is averaged out in our analyses because we only considered periods of at least one year. However, also the daily evolution of EEI, SSC and sediment export in the months after the earthquake was carefully checked and no clear sediment pulses could be identified that could unambiguously be attributed to the earthquake. Our results therefore mainly illustrate that it is very difficult to disentangle the impact of large earthquake events from the impact of other factors that control the temporal variability of sediment export such as the occurrence and magnitude of flood events and land use. This concurs with the findings of Lin J.-C. et al. (2006) and Huang and Montgomery (2012) who concluded that it is very hard to distinguish the impact of the 1999 Chi-Chi earthquake on sediment export from the impact of subsequent rainstorms following this earthquake.

\subsection{Mechanisms behind a seismic impact on catchment sediment yield}

\subsubsection{Landslides triggered by the 1977 earthquake}

Although complete inventories of the landslides caused by the 1977 earthquake are unavailable, it is clear that this event triggered a very substantial number of landslides. For example, Bălteanu (1979) mapped the landslides before and after the 1977 earthquake in a small region close to the epicenter and reported 20 to 50 -fold increases in landsliding due to this event. Compiling earlier studies on earthquake-triggered landslides worldwide, Keefer (2002) reported a relationship between the magnitude of an earthquake and the area affected 
by landslides. Likewise, based on 16 earthquakes for which complete landslide inventories were available, Malamud et al. (2004) proposed a relationship between earthquake magnitude and the volume of sediments generated by earthquake-triggered landslides. The application of these relationships to the $7.4 \mathrm{Mw}$ earthquake of 1977 , indicates that this earthquake could have generated ca. $1.77 \times 10^{8} \mathrm{~m}^{3}$ of landslide material over an area of $8710 \mathrm{~km}^{2}$. Assuming a relatively conservative dry bulk density of $1.5 \mathrm{t} \mathrm{m}^{-3}$, this corresponds to a mean value of $3.05 \times 10^{4} \mathrm{t} \mathrm{km}^{-2}$. Hence, the pulse of sediments that could have been triggered by the 1977 earthquake was about 17 times larger than the highest observed annual catchment $S Y$ considered in this study (i.e. Jilişte catchment, $1784 \mathrm{t} \mathrm{km}^{-2} \mathrm{y}^{-1}$; Table 2). Despite their inevitable uncertainties, these calculations clearly indicate that the 1977 earthquake was large enough to cause a major pulse of landslides that potentially affected the sediment export of the studied river systems.

The results of this study therefore lead to two important questions. Firstly: why does such a significant landslide-causing earthquake event have no clearly distinguishable impact on the suspended sediment export in the years after this event? Secondly: if major earthquakes like the one of 1977 have no clear impact on the temporal variability of suspended sediment export, why do we observe such a strong spatial correlations between seismic activity and long-term average $S Y$ ?

\subsubsection{Why do landslide-causing earthquakes not necessarily affect short-term suspended} sediment export?

Regarding the first question noted in the previous section, several reasons may explain why suspended sediment export is not affected by large earthquake-triggered landslide events. Firstly, earlier studies indicated the importance of connectivity when assessing the impact of landslides on sediment fluxes (e.g. de Vente et al., 2006; Cavalli et al., 2013). Overall, for only a fraction of the earthquake-triggered landslides, the runout zone will reach the river system. As a result, only part of the produced sediments will be available for sediment export. Assessing the sediment delivery of landslides to rivers remains a major challenge. However, some studies suggest that often only a small fraction of the landslides will directly contribute to the catchment sediment export (e.g. de Vente et al., 2006; Borselli et al., 2008; Cavalli et al., 2013). Earlier studies also indicated that earthquake-triggered landslides are often located higher on hillslopes, and hence further away from the river channel, compared to rainfalltriggered landslides (Densmore and Hovius, 2000; Meunier et al., 2008). Hence, the 
contribution of earthquake-triggered landslides to sediment export might overall be even smaller than for rainfall-triggered landslides.

Secondly, it should be noted that this study only considered suspended sediment export, whereas many earthquake-triggered landslides often mainly consist of coarser sediments, i.e. gravel and boulders (e.g. Keefer, 2002). Hence, such landslides may have only a limited direct impact on the suspended sediment load, even if they reach the river system. Nonetheless, they may have a significant and long-lasting impact on the bedload transport of the river. Earlier studies showed that large earthquake-triggered landslide events can choke river systems with coarse sediments. Evacuating these sediments may require decades or even centuries (Pearce and Watson, 1986; Yanites et al., 2010, 2011). The studied earthquake of 1977 (Table 1; Fig. 1) may have had a similar impact on the rivers in the Vrancea region. Whereas most rivers in the Siret basin show a trend of degradation over the last decades, the higher reaches of the Putna river, which are located close to the epicenter (Table 2, Fig. 1), show a clear aggradation (Rădoane et al., 2013). This aggradation was especially apparent between 1975 and 1985 (i.e. the decade of the 1977 earthquake) and are most likely not linked to land use changes, since significant reforestations took place in this catchment during the last decades (Rădoane et al., 2013).

A third reason explaining why the 1977 earthquake did not cause a sudden increase in suspended sediment export may be the occurrence of delays between the earthquake and its associated landslides. Earlier studies reported that landslides associated with a large earthquake event can occur months after the actual earthquake and may be triggered by a rainfall event or a smaller earthquake (e.g. Keefer, 2002; Hovius et al., 2011; Parker, 2013). As a result, the actual triggering mechanism of landslides is difficult to identify (e.g. Huang and Montgomery, 2012). Likewise, Lin J.-C. et al. (2006) demonstrated that the spatial extent of landslides triggered by an earthquake can substantially increase by rainfall events after the earthquake, leading to a gradual rather than a sudden increase in suspended sediment export.

\subsubsection{Why do earthquakes affect long-term average suspended sediment yield}

The last reason written in the previous section also provides a potential answer to our second question. The occurrence of earthquakes in the Vrancea region (Fig. 1) not necessarily results in clear and distinct landslide events that cause pulses in sediment export, but more likely in an overall higher supply of sediments due to mass wasting. Based on a review of studied earthquake-triggered landslide events, Malamud et al. (2004) indicate that earthquaketriggered mass movements may occur from earthquakes with $M w>4$. Such earthquakes occur 
frequently in the Vrancea region $(n=530$ between 1900 and 1977; NIEP, 2012). Also a nation-wide analysis of landslides in Romania showed that the Vrancea region is overall very susceptible to landsliding due to its overall high rate of seismic activity (Bălteanu et al., 2010). This, in combination with the possibility that landslides are not always triggered directly by the earthquake, may help explaining why long-term average $S Y$ is strongly correlated with seismic activity (Fig. 2a) while a major earthquake event shows no clearly identifiable impact on the temporal variability of sediment export.

This may also potentially explain why several catchments close to the epicenter showed no significant increase in EEI after the 1977 earthquake, while catchments further away did (Fig. 7). The epicenter of this earthquake fell in the heart of the Vrancea region, where earthquakes and landslides occur very frequently (Fig. 1; Bălteanu et al., 2010). Hence, it can be expected that sediment supply due to landslides is already very high in this region and that the relative increase in sediment supply to the river system due to the 1977 earthquake was only limited. This is also indicated by the fact that catchments close to the epicenter generally have much higher EEI values compared to the catchments in the North of the Siret basin (Fig. 7). The latter catchments are generally much less susceptible to earthquake-triggered landsliding (Bălteanu et al., 2010). However, according to an empirical relationship proposed by Keefer (2002), the $7.4 \mathrm{Mw}$ earthquake of 1977 could have easily triggered landslides up to $300 \mathrm{~km}$ away from the epicenter. Hence, it is possible that the significant increase in EEI in these catchments is indeed due to the contribution of landslides triggered by the 1977 earthquake (Fig. 7). Nonetheless, it should be stressed that this explanation remains highly uncertain. As we discussed in Section 5.2, variations in the relationship between $Q$ and SSC show an important intrinsic variability (Fig. 6). The causes of these variations are often linked to specific catchments and weather conditions but are currently impossible to identify. As a result, the observed changes in EEI may also be related to other reasons such as the occurrence of specific flood events.

There are additional reasons why earthquake-triggered landslides may affect long-term average $S Y$ but are not necessarily reflected in the temporal variations in sediment export. For example, areas that are affected by recent landslides are often devoid of vegetation, located on steep slopes and therefore prone to various other water erosion processes. Lin W.-T. et al. (2006) report six-fold increases in sheet and rill erosion rates due to this effect. As the vegetation recovery of landslide-affected areas often requires several years (Lin W.-T. et al., 2006), this increased susceptibility to water erosion processes may lead to an increase in average $S Y$. Furthermore, whereas the input of coarse sediments (i.e. gravel and boulders) 
from earthquake-triggered landslides may not have an immediate impact on suspended sediment export, the abrasion of these sediments due to their transportation as bedload (Parker, 1991) may also contribute to the suspended sediment load over longer time periods. Likewise, earthquake-triggered landslides can dam rivers and temporarily prevent fine fractions of sediments from directly contributing to the suspended sediment export (Pearce and Watson, 1986).

Finally, it should be acknowledged that, apart from earthquake-triggered landsliding, other processes may contribute to the observed strong correlation between seismic activity and average $S Y$ (Fig. 2a). As indicated in the introduction, tectonic movements associated with earthquakes can result in river incision and, hence, increased sediment export rates (e.g. Whittaker et al., 2010; Larsen and Montgomery, 2012). Yanites et al. (2010) indicate that also at the time scale of contemporary $S Y$ measurements (i.e. decades), these incision rates can be considerable. Likewise, tectonic activity often results in significant rock fracturing while spatial patterns of these fractures can often be expected to be strongly correlated with patterns of seismic activity (Molnar et al., 2007). Various studies clearly indicate that the occurrence of such seismic fractures can have a strong, often underestimated, effect on weathering rates and can therefore increase the susceptibility of the rocks to various erosion processes (e.g. Molnar et al., 2007; Cox et al., 2010; Clarke and Burbank, 2011; Koons et al., 2012). Hence, the strong observed correlation between $S Y$ and seismic activity may also be partly attributed to spatial differences in rock weathering and erodibility within the Siret basin.

It should also be noted that these different possible explanations may reinforce each other. For example, both river incision and seismic rock fracturing may lead to an increased susceptibility to earthquake-triggered landsliding (e.g. Clarke and Burbank, 2011; Larsen and Montgomery, 2012). Overall, the importance of these different mechanisms and their potential interactions are currently poorly understood (e.g. Molnar et al., 2007; Egholm et al., 2013; Vanmaercke et al., in press).

\section{Conclusions}

This study demonstrated that differences in average annual catchment sediment yield $(S Y)$ in the Siret basin are mainly explained by the overall degree of seismic activity (expressed as $P G A$ ) and the catchment lithology. $P G A$ alone explained $74 \%$ of the observed variation in $S Y$ (Fig. 2a), while also considering lithology resulted in an explained variance of $80 \%$ (Fig. 3). Other factors (e.g. topography, runoff and land use) did not significantly contribute to the explained variance. Evidently these results should be interpreted with caution, since they were 
based on the analyses of a fairly limited number of catchments $(n=38)$ in one specific region, that represented important differences in seismic activity. Nonetheless, they illustrate that seismic activity may exert a more important impact on $S Y$ than other factors that are commonly considered to have a dominant impact on sediment fluxes, i.e. land use and topography. Recent studies highlighted that, because of their vast extent, areas with a low to moderate topography have a dominant impact on the global sediment flux to the ocean (Willenbring et al., 2013; Kirchner and Ferrier, 2013). Nonetheless, explaining the observed variation in denudation rates for these regions currently remains very difficult. As this study demonstrates, seismic activity may be an important but hitherto rarely considered factor in explaining this variation.

Secondly, we explored the impact of a large earthquake event on the temporal variability of sediment export. Based on earlier research (Hovius et al., 2011), it was expected that earthquake-triggered landslides would result in an increased sediment transport in the years after the earthquake. Although the $7.4 \mathrm{Mw}$ earthquake of 1977 caused a significant number of landslides, nine out of ten studied rivers showed no clear increase in suspended sediment export after the earthquake. This mainly illustrates that the response of a catchment to an earthquake may be complex and remains difficult to predict.

Whereas seismic activity was found to have a dominant impact on the spatial variability of average $S Y$ over decadal time scales, temporal variations in sediment export at shorter time scales $(<5 \mathrm{yr})$ seem, to a large extent, to be controlled by other factors. This could indicate that earthquake-triggered landslides may affect $S Y$ mainly in an indirect way, or that observed correlations between $S Y$ and seismic activity are (partly) affected by other processes such as tectonic uplift and rock fracturing than earthquake-triggered landsliding.

Several mechanisms that may explain the apparent discrepancy between spatial and temporal variation in sediment export are discussed and may guide further research.

\section{Acknowledgments}

F. Obreja was financially supported within the project entitled "Doctorate: an Attractive Research Career", contract number POSDRU/107/1.5/S/77946, co-financed by European Social Fund through Sectorial Operational Programme for Human Resources Development 2007-2013. M. Vanmaercke acknowledges his postdoctoral research grant from the Research Foundation Flanders (FWO), Brussels, Belgium. We acknowledge Christopher J. Thompson and an anonymous reviewer for their constructive comments. 


\section{References}

Aalto, R., Dunne, T., Guyot, J., 2006. Geomorphic Controls on Andean Denudation Rates. The Journal of Geology 114, 85-99.

Airinei, S., 1977. Microplăci litosferice pe teritoriul României, SC GGG, seria Geologie, 15.

Alexandrov, Y., Laronne, J.B., Reid, I., 2007. Intra-event and inter-seasonal behaviour of suspended sediment in flash floods of the semi-arid northern Negev, Israel. Geomorphology 85, 85-97.

Asselman, N., 2000. Fitting and interpretation of sediment rating curves. Journal of Hydrolgy 234, 228-248.

Balan, S., Cristescu, V., Cornea, I., 1982. Cutremurul de pământ din România de la 4 martie 1977, Editura Academiei. București.

Bălteanu, D., 1979. Procese de modelare a versanţilor declanşate de cutremurul din 4 martie 1977 în Carpaţii şi Subcarpaţii Buzăului, SC GGG, seria Geografie, t.26, Bucureşti.

Bălteanu, D., Chendes, V., Sima, M., Enciu, P., 2010. A country-wide spatial assessment of landslide susceptibility in Romania, Geomorphology 124, 102-112.

Borselli, L., Cassi, P., Torri, D., 2008. Prolegomena to sediment and flow connectivity in the landscape: a GIS and field numerical assessment. Catena 75, 268-277.

Bruijnzeel, L.A., 2004. Hydrological functions of tropical forests: not seeing the soil for the trees? Agriculture, Ecosystems and Environment 104, 185-228.

Cavalli, M., Trevisani, S., Comiti, F., Marchi, L., 2013. Geomorphometric assessment of spatial sediment connectivity in small Alpine catchments. Geomorphology 188, 31-41.

CGIAR, 2008. SRTM 90 m Digital Elevation Data. Available online: http: //srtm.csi.cgiar.org/ (last accessed: 20 July 2013).

Clarke, B.A., Burbank, D.W., 2011. Quantifying bedrock - fracture patterns within the shallow subsurface: Implications for rock mass strength, bedrock landslides, and erodibility. Journal of Geophysical Research 116, F04009, doi:10.1029/2011JF001987.

Constantinescu, L., Marza, V.I., 1980. A computer-compiled and computer-oriented catalogue of Romania's earthquakes during a millennium (AD 984-1979), Rev. Roum. Geophys. 24, 193234.

Constantinescu, L., Enescu, D., 1985. Cutremurele din Vrancea în cadrul științific și tehnologic. Editura Academiei. Bucuresti.

Cox, R., Zentner, D.B., Rakotondrazafy, A.M.F., Rasoazanamparany, C.F., 2010. Shakedown in Madagascar: Occurrence of lavakas (erosional gullies) associated with seismic activity. Geology 38, 179-182.

Dadson, S.J., Hovius, N., Chen, H., Dade, W.B., Hsieh, M-L., Willet, S.D., Hu, J-C., Horng, M-J., Chen, M-C., Stark, C.P., Lague, D., Lin, J-C., 2003. Links between erosion, runoff variability and seismicity in the Taiwan orogen. Nature 426, 648-651.

Dadson, S., Hovius, N., Chen, H., Dade, W., Lin, J., Hsu, M., Lin, C., Ming-Jame, H., Chen, T., Milliman, J., Stark, C., 2004. Earthquake-triggered increase in sediment delivery from an active mountain belt. Geology 32, 733-736.

Densmore, A.L., Hovius, N., 2000. Topographic fingerprints of bedrock landslides. Geology 28, 371374.

de Vente, J., Poesen, J., 2005. Predicting soil erosion and sediment yield at the basin scale: Scale issues and semi-quantitative models. Earth-Science Reviews 71, 95-125. 
de Vente, J., Poesen, J., Bazzoffi, P., Van Rompaey, A., Verstraeten, G., 2006. Predicting catchment sediment yield in Mediterranean environments: the importance of sediment sources and connectivity in Italian drainage basins. Earth Surface Processes and Landforms 31, 10171034.

de Vente, J., Verduyn, R., Verstraeten, G., Vanmaercke, M., Poesen, J., 2011. Factors controlling sediment yield at the catchment scale in NW Mediterranean geoecosystems. Journal of Soils and Sediments 11, 690-707.

de Vente, J., Poesen, J., Verstraeten, G., Govers, G., Vanmaercke, M., Van Rompaey, A., Arabkhedri, M., Boix-Fayos, C., 2013. Predicting soil erosion and sediment yield at regional scales: where do we stand? Earth-Science Reviews 127, 16-29.

Diaconu, C., Lăzărescu, D., 1965. Hidrologie. Editura Didactică şi Pedagogică, Bucureşti.

Diaconu, C., Lăzărescu, D., Mociorniţa, C., 1970. Aspecte hidrologice ale viiturilor pe unele râuri interioare din primăvara anului 1970, Hidrotehnica, nr. 12, Bucureşti.

Diaconu, C., 1971. Probleme ale scurgerii aluviunilor pe râurile din România, St. de Hidrologie, XXX, IMH Bucureşti.

Diaconu, C., Serban, P., 1994. Synthesis and Hydrological Regionalizations. Editura Tehnica, Bucuresti, 388 pp.

DiBiasi, R., Whipple, K., Heisath, A., Ouimet, W., 2010. Landscape form and millennial erosion rates in the San Gabriel Mountains, CA. Earth and Planetary Science Letters 289, 134-144.

EEA, 2010. Corine Land Cover 1990 raster data - version 13 (02/2010). Available online: http: //www.eea.europa.eu/data-and-maps/data/corine-land-cover-1990-raster (last accessed: 15 July 2013).

Egholm, D.L., Knudsen, M.F., Sandford, M., 2013. Lifespan of mountain ranges scaled by feedbacks between landsliding and erosion by rivers. Nature 498, 475-478.

Fisher, R.A., 1924. The distribution of the partial correlation coefficient. Metron 3, 329-332.

Geological Institute of Romania, 1960. Geological Map of Romania, Scale 1/25000.

Hovius, N., Meunier, P., Ching-Weei, L., Hongey, C., Yue-Gau, C., Dadson, S., Ming-Jame, H., Lines, M., 2011. Prolonged seismically induced erosion and the mass balance of a large earthquake. Earth and Planetary Science Letters 304, 347-355.

Huang, M.Y.F., Montgomery, D.R., 2012. Fluvial response to rapid episodic erosion by earthquake and typhoons, Tachia River, central Taiwan. Geomorphology 175/176, 126-138.

NIHWM, 1997. Instructions for hydrological stations and services. Water and sediment discharge. Instruction manual by the National Institute of Hydrology and Water Management, Bucharest.

Keefer, D.K., 2002. Investigating landslides caused by earthquakes-a historical review. Surveys in Geophysics 23, 473-510.

Kirchner, J.W., Ferrier, K.L., 2013. Mainly in the plain. Nature 495, 318-319.

Koons, P.O., Upton, P., Barker, A.D., 2012. The influence of mechanical properties on the link between tectonic and topographic evolution. Geomorphology 137, 168-180.

Larsen, I.J., Montgomery, D.R., 2012. Landslide erosion coupled to tectonics and river incision. Nature Geoscience 5, 468-473.

Lin, J.-C., Petley, D., Jen, C.-H., Koh, A., Hsu, M.-L., 2006. Slope movements in a dynamic environment - A case study of Tachia River, Central Taiwan. Quaternary International 147, $103-112$. 
Lin, W.-T., Lin, C.-Y., Choun W.-C., 2006. Assessment of vegetation recovery and soil erosion at landslides caused by a catastrophic earthquake: A case study in Central Taiwan. Ecological Engineering 28, 79-89.

Lungu, D., Arion, C., Aldea, A., Vacareanu, R., 2004. Reprezentation of seismic action in the new Romanian code for design of earthquake resistant buildings P100-2003. 13th World Conference on Earthquake Engineering Vancouver, B.C., Canada August 1-6, 2004 Paper No. 1796.

Malamud, B.D., Turcotte, D.L., Guzzetti, F., Reichenbach, P., 2004. Landslides, earthquakes, and erosion. Earth and Planetary Science Letters 229, 45-59.

Markus, M., Demissie, M., 2006. Predictability of annual sediment loads based on flood events. Jour. Hydraul. Eng. 11, 354-361.

Merritt, W., Letcher, R., Jakeman, A., 2003. A review of erosion and sediment transport models. Environ Model Softw 18, 761-799.

Meunier, P., Hovius, N., Haines, J.A., 2008. Topographic site effects and the location of earthquake induced landslides. Earth and Planetary Science Letters 275, 221-232.

Milliman, J.D., Syvitski, J.P.M., 1992. Geomorphic/Tectonic Control of Sediment Discharge to the Ocean: The Importance of Small Mountainous Rivers. The Journal of Geology 100, 525-544.

Moatar, F., Person, G., Meybeck, M., Coynel, A., Etcheber, H., Crouzet, P., 2006. The influence of contrasting suspended particulate matter transport regimes on the bias and precision of flux estimates. Science of the Total Environment 370, 515-531.

Molnar, P., Anderson, R.S., Anderson, S.P., 2007. Tectonics, fracturing of rock, and erosion. Journal of Geophysical Research 112, F03014, doi: 10.1029/2005JF000433.

Montgomery, D.R., Brandon, M.T., 2002. Topographic controls on erosion rates in tectonically active mountain ranges. Earth and Planetary Science Letters 201, 481-489.

Mustăţea, A., 2005. Viituri excepţionale pe teritoriul României. NIHWM, Bucureşti.

Mutihac V., Ionesi L., 1974. Geologia României, Ed. Ştiinţifică, Bucureşti.

Mutihac, V., Stratulat M.I., Fechet R.M., 2004. Geologia Romaniei. Editura Didactica si Pedagogica, R.A.

Nadal-Romero, E., Martínez Murillo, J., Vanmaercke, M., Poesen, J., 2011. Scale-dependency of sediment yield from badland areas in Mediterranean environments. Prog. Phys. Geog. 35, 297-332.

Nash, J.E., Sutcliffe, J.V., 1970. River flow forecasting through conceptual models part I-a discussion of principles. Journal of Hydrology 10, 282-290.

NIEP (National Institute for Earth Physics, Romania), 2012. Romplus Catalogue, 2012. Available online: http://www.infp.ro/catalog-seismic/evenimente.

New, M., Lister, D., Hulme, M., Makin, I., 2002. A high-resolution data set of surface climate over global land areas. Climate Research 21, 1-25.

Obreja, F., 2012. The Sediment Transport of the Siret River during the Floods from 2010, Forum geographic. Studii şi cercetări de geografie şi protecţia mediului, Volume XI, Issue 1 (June 2012), pp. 90-99.

Olariu, P., Obreja, F., Obreja, I., 2009. Unele aspecte privind tranzitul de aluviuni din bazinul hidrografic Trotuş şi de pe sectorul inferior al râului Siret în timpul viiturilor excepţionale din anii 1991 şi 2005. Analele Universităţii „Ştefan cel Mare” Suceava, Sectiunea Geografie anul XVIII.

Oncescu, M.C., Bonjer, K.P., 1997. A note on the depth recurrence and strain release of large intermediate Vrancea earthquakes. Tectonophysics 272, 291-302. 
Oncescu, M.C., Marza, V.I., Rizescu, M., Pop, M., 1999. The Romanian earthquake catalogue between 984-1997. In: F. Wenzel and D. Lungu (Eds.), Contributions from the First International Workshop on Vrancea Earthquakes, Bucharest, Romania, November 1-4, 1997, Kluwer Academic Publishers, 43-48.

Owens, P.N., Batalla, R.J., Collins, A.J., Gomez, B., Hicks, D.M., Horowitz, A.J., Kondolf, G.M., Marden, M., Page, M.J., Peacock, D.H., Petticrew, E.L., Salomons, W., Trustrum, N.A., 2005. Fine-grained sediment in River Systems: environmental significance and management issues. River Research and Applications 21, 693-717.

Parker, G., 1991. Selective Sortain and Abrasion of River Gravel. I: Theory. Jour. Hydraul. Eng. 117, 131-147.

Parker, N.V., 2013. Hillslope memory and spatial and temporal distributions of earthquake-induced landslides. Durham theses, Durham University. Available at Durham E-Theses Online: http://etheses.dur.ac.uk/7761.

Pearce, A.J., Watson, A.J., 1986. Effects of earthquake-induced landslides on sediment budget and transport over a 50-yr period. Geology 14, 52-55.

Perşoiu, I., Rădoane, M., 2011. Spatial and temporal controls on historical channel responses - study of an atypical case: Someşu Mic River, Romania. Earth Surface Landforms and Processes 36, 1391-1409.

Phillips, J., Webb, B., Walling, D., Leeks, G., 1999. Estimating the suspended sediment loads of rivers in the LOIS study area using infrequent samples. Hydrological Processes 13, 1035-1050.

Portenga, E.W., Bierman, P.R., 2011. Understanding Earth's eroding surface with ${ }^{10}$ Be. GSA Today 24, doi: 10.1130/G111A.1.

Podani, M., Zăvoianu, I., 1992. Cauzele şi efectele inundaţiilor produse în luna iulie 1991 în Moldova. Studii şi Cercetări de Geografie XXXIX, Bucureşti.

Rădoane, M., Rădoane, N., 2005. Dams, sediment sources and reservoir silting in Romania. Geomorphology 71, $112-125$.

Rădoane, M., Rădoane, N., Dumitriu, D., 2003. Geomorphological evolution of longitudinal river profiles in the Carpathians. Geomorphology 50, 293 -306.

Rădoane, M., Pandi, G., Rădoane, N., 2010. Contemporary bed elevation changes from the Eastern Carpathians. Carpathian Journal of Earth and Environmental Sciences 5, 49-60.

Rădoane, M., Obreja, F., Cristea, I., Mihailă, D., 2013. Changes in the channel-bed level of the eastern Carpathian rivers: climatic vs. human control over the last 50 years. Geomorphology 193, 91111.

Rădoane, N., Rădoane, M., Olariu, P., Dumitriu, D., 2007. Efectele geomorfologice ale inundaţiilor din 28-29 iulie 2004 în bazine hidrografice mici din Valea Trotuşului. Geografia în contextul dezvoltării durabile, Universitatea "Babeş-Bolyai"Cluj-Napoca.

Radu, C., 1965. Regimul seismic al regiunii Vrancea. SC GGG, Seria Geografie, 3,2.

Raymond, S., Moatar, F., Meybeck, M., Bustillo, V., 2013. Choosing methods for estimating dissolved and particulate riverine fluxes from monthly sampling. Hydrological Sciences Journal 58, 1326-1339.

Sandu, I., Pescaru V.I., Poiana I., 2008. Clima Romaniei. Editura Academiei Romane, Bucureşti.

Săndulescu, M., 1984. Geotectonica României, Ed. Tehnică, Bucureşti.

Shedlock, K., Giardini, D., Grünthal, G., Zhang, P., 2000. The GSHAP Global Seismic Hazard Map. Seismological Research Letters 71, 679-686. 
Steegen, A., Govers, G., Nachtergaele, J., Takken, I., Beuselinck, L., Poesen, J., 2000. Sediment export by water from an agricultural catchment in the Loam Belt of central Belgium. Geomorphology 33, 25-36.

Steel, R.G.D., Torrie, J.H., 1960. Principles and Procedures of Statistics. McGraw-Hill, New York, $672 \mathrm{pp}$.

Syvitski, J.P.M., Milliman, J., 2007. Geology, Geography, and Humans Battle for Dominance over the Delivery of Fluvial Sediment to the Coastal Ocean. The Journal of Geology 115, 1-19.

Vanacker, V., Von Blanckenburg, F., Govers, G., Molina, A., Poesen, J., Deckers, J., Kubik, P., 2007. Restoring dense vegetation can slow mountain erosion to near natural benchmark levels. Geology 35, 303-306.

Vanmaercke, M., Zenebe, A., Poesen, J., Nyssen, J., Verstraeten, G., Deckers, J., 2010. Sediment dynamics and the role of flash floods in sediment export from medium-sized catchments: a case study from the semi-arid tropical highlands in northern Ethiopia. Jour. Soils Sediments 10, 611-627.

Vanmaercke, M., Poesen, J., Rădoane, M., Govers, G., Ocakoglu, F., Arabkhedri, M., 2012. How long should we measure? An exploration of factors controlling the inter-annual variation of catchment sediment yield. Journal of Soils and Sediments 12, 603-619.

Vanmaercke, M., Kettner, A., Van Den Eeckhaut, M., Poesen, J., Mamaliga, A., Verstraeten, G., Rădoane, M., Obreja, F., Upton, P., Syvitski, J., Govers, G., in press. Moderate seismic activity affects contemporary sediment yields. Progress in Physical Geography, doi: $10.1177 / 0309133313516160$.

Walling, D., 1977. Assessing the accuracy of suspended sediment rating curves for a small basin. Water Resources Research 13, 531-538.

Whittaker, A.C., Attal, M., Allen, P.A., 2010. Characterising the origin, nature and fate of sediment exported from catchments perturbed by active tectonics. Basin Research 22, 809-828.

Wilcoxon, F., 1945. Individual Comparisons by Ranking Methods. Biometrics Bulletin 1, 80-83.

Willenbring, J.K., Codilean, A.T., McElroy, B., 2013. Earth is (mostly) flat: Apportionment of the flux of continental sediment over millennial time scales. Geology 41, 343-346.

Yanites, B.J., Tucker, G.E., Mueller, K.J., Chen, Y.-C., 2010. How rivers react to large earthquakes: Evidence from central Taiwan. Geology 38, 639-642.

Yanites, B.J., Tucker, G.E., Hsu, H.-L., Chen, C.-C., 2011. The influence of sediment cover variability on long-term river incision rates: An example from the Peikang River, central Taiwan. Journal of Geophysical Research 116, F03016, doi:10.1029/2010JF001933. 


\section{TABLES}

Table 1. Four strongest earthquakes in terms of magnitude $(M w)$, recorded during the measuring period (1900-2010) in the Vrancea Region (see Fig. 1 for location of the epicenters).

\begin{tabular}{ccccc}
\hline \multirow{2}{*}{ Date } & \multirow{2}{*}{$\begin{array}{c}\text { Magnitude } \\
\end{array}$} & $\begin{array}{c}\text { Epicenter } \\
(M w)\end{array}$ & \multicolumn{2}{c}{ Geographical coordinates } \\
\cline { 4 - 5 } & depth $(\mathrm{km})$ & Latitude $\left({ }^{\circ}\right)$ & Longitude $\left(^{\circ}\right)$ \\
\hline 10.11 .1940 & 7.6 & 150 & 45.7994 & 26.6975 \\
04.03 .1977 & 7.4 & 94 & 45.7692 & 26.7575 \\
30.08 .1986 & 7.1 & 132 & 45.5189 & 26.4881 \\
30.05 .1990 & 6.9 & 91 & 45.8297 & 26.8883 \\
\hline
\end{tabular}


Table 2. Measured average annual runoff $(R o)$ and sediment yield $(S Y)$ for the 38 selected subcatchments in the Siret river basin. 'Nr.' indicates the gauging station number, also shown in Fig. 1.

\begin{tabular}{|c|c|c|c|c|c|c|c|}
\hline \multirow{2}{*}{ Nr. } & \multirow{2}{*}{ River } & \multirow{2}{*}{$\begin{array}{l}\text { Gauging } \\
\text { station }\end{array}$} & \multicolumn{2}{|c|}{ Location Gauging Station } & \multirow{2}{*}{$\begin{array}{c}\text {-Measuring } \\
\text { Period }\end{array}$} & \multirow{2}{*}{$R o\left(\mathrm{~mm} \mathrm{y}^{-1}\right)$} & \multirow{2}{*}{$S Y\left(\mathrm{t} \mathrm{km}^{-2} \mathrm{y}^{-1}\right)$} \\
\hline & & & Latitude $\left({ }^{\circ}\right)$ & Longitude $\left(^{\circ}\right)$ & & & \\
\hline 1 & Suceava & Brodina & 47.8867 & 25.4219 & $1971-2010$ & 371 & 284.5 \\
\hline 2 & Soloneț & Părhăuți & 47.7119 & 26.0861 & $1973-2010$ & 192 & 464.1 \\
\hline 3 & Suceava & Ițcani & 47.6719 & 26.2472 & $1957-2010$ & 228 & 208.2 \\
\hline 4 & Moldova & Prisaca Dornei & 47.5400 & 25.6611 & $1958-2010$ & 426 & 152.1 \\
\hline 5 & Moldovița & Dragoşa & 47.6147 & 25.6081 & $1971-2010$ & 345 & 204.5 \\
\hline 6 & Râșca & Bogdănești & 47.3606 & 26.2503 & $1965-2010$ & 260 & 174.4 \\
\hline 7 & Moldova & Tupilați & 47.0847 & 26.6483 & 1959-2010 & 262 & 298.9 \\
\hline 8 & Bistrița & Dorna Giumalău & 47.3608 & 25.3497 & $1956-2010$ & 499 & 87.4 \\
\hline 9 & Dorna & Dorna Candreni & 47.3556 & 25.2817 & 1959-2010 & 421 & 55.9 \\
\hline 10 & Bistrița & Dorna Arini & 47.3433 & 25.4089 & $1960-2010$ & 469 & 76.6 \\
\hline 11 & Neagra & Broşteni & 47.1992 & 25.6833 & $1965-2010$ & 411 & 58.4 \\
\hline 12 & Bistriţa & Frumosu & 47.1422 & 25.8622 & 1967-2010 & 421 & 101.6 \\
\hline 13 & Bolătău & Poiana Largului & 47.0950 & 25.9731 & $1978-2010$ & 257 & 214.0 \\
\hline 14 & Bistricioara & Tulgheș & 46.9647 & 25.7581 & 1965-2010 & 240 & 59.6 \\
\hline 15 & Bistricioara & Bistricioara & 47.0572 & 25.9128 & 1974-2010 & 259 & 112.9 \\
\hline 16 & Cracău & Slobozia & 46.8393 & 26.5298 & 1956-2010 & 128 & 163.1 \\
\hline 17 & Trotuş & Lunca de Sus & 46.5347 & 25.9553 & 1976-2010 & 285 & 100.4 \\
\hline 18 & Trotuş & Goioasa & 46.4447 & 26.2997 & $1980-2010$ & 264 & 194.0 \\
\hline 19 & Asău & Asău & 46.4508 & 26.4008 & $1977-2010$ & 315 & 324.9 \\
\hline 20 & $\mathrm{Uz}$ & Valea Uzului & 46.3428 & 26.2608 & 1969-2010 & 350 & 84.2 \\
\hline 21 & Trotuş & Târgu Ocna & 46.2769 & 26.6047 & $1957-2010$ & 262 & 270.1 \\
\hline 22 & Oituz & Ferăstrău & 46.2042 & 26.5867 & 1973-2010 & 367 & 248.2 \\
\hline 23 & Trotuş & Vrânceni & 46.2097 & 26.8950 & $1966-2010$ & 267 & 342.4 \\
\hline 24 & Tazlău & Helegiu & 46.3514 & 26.7417 & $1971-2010$ & 213 & 401.6 \\
\hline 25 & Șuşița & Ciuruc & 45.9984 & 26.8305 & $1961-2010$ & 234 & 836.8 \\
\hline 26 & Putna & Tulnici & 45.9078 & 26.6647 & 1959-2010 & 208 & 363.0 \\
\hline 27 & Zăbala & Nereju & 45.7169 & 26.7369 & 1974-2010 & 210 & 1163.9 \\
\hline 28 & Putna & Colacu & 45.8883 & 26.8403 & $1974-2010$ & 164 & 1141.0 \\
\hline 29 & Putna & Boțârlău & 45.6331 & 27.3864 & $1956-2010$ & 117 & 1137.4 \\
\hline 30 & Milcov & Golești & 45.6672 & 27.1622 & $1957-2010$ & 55 & 1710.0 \\
\hline 31 & Râmna & Jiliște & 45.6037 & 27.2405 & $1971-2010$ & 42.6 & 1784.0 \\
\hline 32 & Râmnicu Sărat & Tulburea & 45.5603 & 26.8317 & 1964-2010 & 268 & 1603.2 \\
\hline 33 & Râmnicu Sărat & Tătaru & 45.5036 & 27.4889 & 1956-2010 & 76.2 & 816.0 \\
\hline 34 & Buzău & Sita Buzău & 45.6608 & 26.0686 & 1950-2010 & 509 & 318.2 \\
\hline 35 & Câlnău & Potârnichești & 45.2200 & 26.8542 & $1965-2010$ & 63.8 & 1345.3 \\
\hline 36 & Slănic & Cernătești & 45.2692 & 26.7550 & $1968-2010$ & 103 & 1151.6 \\
\hline 37 & Bâsca & Bâsca Rozilei & 45.4525 & 26.3383 & $1960-2010$ & 494 & 376.0 \\
\hline 38 & Bâsca Mică & Varlaam II & 45.5200 & 26.4489 & $1963-2010$ & 466 & 533.4 \\
\hline
\end{tabular}


Table 3. Overview, explanation and data sources of the variables considered in the spatial correlation analyses of average catchment sediment yields in the Siret basin.

\begin{tabular}{|c|c|c|c|}
\hline Variable & Description & Derived from & Units \\
\hline$A$ & Originally reported catchment area & $\begin{array}{l}\text { "Romanian Water" National } \\
\text { Administration }\end{array}$ & $\mathrm{km}^{2}$ \\
\hline$E D$ & $\begin{array}{l}\text { Earthquake density, calculated as the number of epicentres in the } \\
\text { catchment per unit of catchment area for all registered }(M w> \\
\text { 0.5) earthquakes between } 1900 \text { and } 2010\end{array}$ & $\begin{array}{l}\text { Constantinescu and Marza (1980); } \\
\text { Oncescu and Bonjer (1997); Oncescu } \\
\text { et.al. (1999); NIEP (2012) }\end{array}$ & $\mathrm{km}^{-2}$ \\
\hline$C M D$ & $\begin{array}{l}\text { Cumulative magnitude density, calculated as the sum of the } \\
\text { moment magnitudes of all registered earthquakes within the } \\
\text { catchment }(M w>0.5) \text { during the period 1900-2010, divided } \\
\text { by the catchment area }\end{array}$ & $\begin{array}{l}\text { Constantinescu and Marza (1980); } \\
\text { Oncescu and Bonjer (1997); Oncescu } \\
\text { et.al. (1999); NIEP (2012) }\end{array}$ & $\mathrm{M}_{\mathrm{w}} \mathrm{km}^{-2}$ \\
\hline$P G A$ & $\begin{array}{l}\text { Catchment average of the expected peak ground acceleration } \\
\text { with a recurrence interval of } 100 \text { years }\end{array}$ & Lungu et al. (2004) & $\mathrm{ms}^{-2}$ \\
\hline $\begin{array}{l}\text { Dominant } \\
\text { Lithology }\end{array}$ & Dominant lithological unit in the catchment & Geological Institute of Romania (1960) & none \\
\hline$L$ & $\begin{array}{l}\text { Catchment lithology erodibility factor, as proposed by Syvitski } \\
\text { and Milliman (2007). To each lithology class, a score was } \\
\text { assigned that indicates its expected erodibility (crystalline and } \\
\text { volcanic rocks: } 0.5 \text {; Flysch: } 1 \text {; Platform and Quaternary rocks: } \\
\text { 1.5; Molasse: } 2 \text { ). } L \text { was then calculated as the area-weighted } \\
\text { average of these lithology scores. High } L \text { values indicate } \\
\text { catchments with an erodible lithology. }\end{array}$ & Geological Institute of Romania (1960) & none \\
\hline$R$ & Total relief & CGIAR (2008) & $\mathrm{m}$ \\
\hline Slope & Average catchment slope & CGIAR (2008) & $\circ$ \\
\hline$M L R$ & $\begin{array}{l}\text { Mean Local Relief, where local relief is the maximum height } \\
\text { difference within a radius of } 5000 \mathrm{~m}\end{array}$ & CGIAR (2008) & $\mathrm{m}$ \\
\hline Forest & $\begin{array}{l}\text { Aerial percentage of forest in each catchment, derived from the } \\
\text { CORINE } 1990 \text { land cover database }\end{array}$ & EEA (2010) & $\%$ \\
\hline$A L$ & $\begin{array}{l}\text { Aerial percentage of arable land in each catchment, derived from } \\
\text { the CORINE } 1990 \text { land cover database }\end{array}$ & EEA (2010) & $\%$ \\
\hline$P$ & Average annual rainfall (1961-1990) & New et al. (2002) & $\mathrm{mm}$ \\
\hline Ro & Mean measured annual runoff depth & $\begin{array}{l}\text { "Romanian Water" National } \\
\text { Administration }\end{array}$ & $\mathrm{mm}$ \\
\hline
\end{tabular}


Table 4. Properties of the 38 selected subcatchments of the Siret basin. 'Nr.' refers to the numbers indicated in Fig. $1 . A=$ catchment area; $E D=$ earthquake density; $C M D=$ cumulative magnitude density; $P G A=$ expected peak ground acceleration with a recurrence interval of 100 years; $L=$ lithology score; $R=$ total catchment relief. Slope = average catchment slope; $M L R=$ mean local relief; Forest = percentage forest cover in 1990; $A L=$ percentage of arable land in 1990; $P=$ average annual rainfall depth; $R o=$ averaged measured runoff depth. See text for explanation on how these catchment characteristics were derived. See Table 3 for a detailed explanation of these factors.

\begin{tabular}{|c|c|c|c|c|c|c|c|c|c|c|c|c|c|c|}
\hline Nr. & Gauging Station (River) & $A\left(\mathrm{~km}^{2}\right)$ & $E D\left(\mathrm{~km}^{-2}\right)$ & $\begin{array}{c}C M D \\
\left(M w \mathrm{~km}^{-2}\right)\end{array}$ & $\begin{array}{l}P G A \\
\left(\mathrm{~ms}^{-2}\right)\end{array}$ & $\begin{array}{c}\text { Dominant } \\
\text { lithology * }\end{array}$ & $L$ & $R(\mathrm{~m})$ & $\begin{array}{l}\text { Slope } \\
\left({ }^{\circ}\right)\end{array}$ & $\begin{array}{c}M L R \\
(\mathrm{~m})\end{array}$ & $\begin{array}{c}\text { Forest } \\
(\%)\end{array}$ & $A L(\%)$ & $P\left(\mathrm{~mm} \mathrm{y}^{-1}\right)$ & $R o\left(\mathrm{~mm} \mathrm{y}^{-1}\right)$ \\
\hline 1 & Brodina (Suceava) & 366 & 0.000 & 0.000 & 0.90 & $\mathrm{~F}$ & 1.0 & 952 & 14.8 & 561 & 33.2 & 18.1 & 784 & 371 \\
\hline 2 & Părhăuți (Soloneț) & 204 & 0.000 & 0.000 & 1.18 & $P \& Q$ & 1.4 & 643 & 6.8 & 294 & 33.5 & 49.7 & 627 & 192 \\
\hline 3 & Ițcani (Suceava) & 2334 & 0.000 & 0.000 & 1.34 & $P \& Q$ & 1.3 & 1265 & 8.2 & 350 & 32.9 & 38.4 & 680 & 228 \\
\hline 4 & Prisaca Dornei (Moldova) & 664 & 0.002 & 0.006 & 0.86 & $\mathrm{C}$ & 0.7 & 1272 & 14.9 & 644 & 55.8 & 22.7 & 772 & 426 \\
\hline 5 & Dragoșa (Moldovița) & 463 & 0.002 & 0.010 & 1.08 & $\mathrm{~F}$ & 1.0 & 888 & 13.7 & 531 & 80.2 & 11.9 & 747 & 345 \\
\hline 6 & Bogdănești (Râșca) & 181 & 0.006 & 0.014 & 1.57 & $\mathrm{~F}$ & 1.4 & 821 & 11.5 & 489 & 89.3 & 7.6 & 634 & 260 \\
\hline 7 & Tupilați (Moldova) & 3928 & 0.003 & 0.010 & 1.55 & $\mathrm{~F}$ & 1.2 & 1611 & 10.6 & 469 & 55.8 & 27.5 & 670 & 262 \\
\hline 8 & Dorna Giumalău (Bistrița) & 758 & 0.001 & 0.003 & 0.78 & C & 0.5 & 1445 & 17.1 & 680 & 75.5 & 0.0 & 831 & 499 \\
\hline 9 & Dorna Candreni (Dorna) & 565 & 0.014 & 0.038 & 0.78 & $\mathrm{v}$ & 0.6 & 1158 & 12.0 & 603 & 74.4 & 0.0 & 801 & 421 \\
\hline 10 & Dorna Arini (Bistrița) & 1690 & 0.006 & 0.016 & 0.78 & C & 0.6 & 1458 & 14.7 & 669 & 59.5 & 0.8 & 818 & 469 \\
\hline 11 & Broșteni (Neagra) & 292 & 0.014 & 0.046 & 0.84 & $\mathrm{C}$ & 0.5 & 1264 & 18.1 & 749 & 84.7 & 1.0 & 791 & 411 \\
\hline 12 & Frumosu (Bis trița) & 2858 & 0.005 & 0.015 & 1.06 & $\mathrm{C}$ & 0.6 & 1698 & 16.5 & 737 & 69.8 & 2.5 & 798 & 421 \\
\hline 13 & Poiana Largului (Bolătău) & 59 & 0.000 & 0.000 & 1.57 & $\mathrm{~F}$ & 1.0 & 799 & 14.8 & 647 & 66.3 & 4.5 & 677 & 257 \\
\hline 14 & Tulgheș (Bistricioara) & 408 & 0.000 & 0.000 & 0.92 & C & 0.5 & 1010 & 16.3 & 690 & 61.9 & 5.8 & 768 & 240 \\
\hline 15 & Bistricioara (Bistricioara) & 760 & 0.003 & 0.006 & 1.27 & $\mathrm{C}$ & 0.6 & 1145 & 17.3 & 740 & 66.5 & 5.8 & 751 & 259 \\
\hline 16 & Slobozia (Cracău) & 445 & 0.002 & 0.007 & 1.97 & M & 1.7 & 945 & 7.5 & 340 & 33.4 & 39.6 & 605 & 128 \\
\hline 17 & Lunca de Sus (Trotuș) & 88 & 0.000 & 0.000 & 1.57 & $\mathrm{~F}$ & 0.8 & 568 & 14.7 & 458 & 13.4 & 0.1 & 742 & 285 \\
\hline 18 & Goioasa (Trotuș) & 781 & 0.003 & 0.007 & 1.85 & $\mathrm{~F}$ & 1.0 & 1167 & 16.2 & 711 & 45.7 & 13.0 & 745 & 264 \\
\hline 19 & Asău (Asău) & 204 & 0.000 & 0.000 & 2.23 & $\mathrm{~F}$ & 1.0 & 980 & 17.1 & 671 & 90.9 & 1.7 & 703 & 315 \\
\hline 20 & Valea Uzului (Uz) & 150 & 0.007 & 0.015 & 1.96 & $\mathrm{~F}$ & 1.0 & 906 & 15.7 & 605 & 77.1 & 0.0 & 743 & 350 \\
\hline 21 & Târgu Ocna (Trotuș) & 2091 & 0.009 & 0.022 & 2.42 & $\mathrm{~F}$ & 1.0 & 1406 & 15.2 & 685 & 56.2 & 9.0 & 711 & 262 \\
\hline 22 & Ferăstrău (Oituz) & 267 & 0.015 & 0.032 & 2.52 & $\mathrm{~F}$ & 1.0 & 1206 & 15.0 & 684 & 65.8 & 1.3 & 709 & 367 \\
\hline 23 & Vrânceni (Trotuș) & 4092 & 0.010 & 0.022 & 2.82 & $\mathrm{~F}$ & 1.6 & 1495 & 12.9 & 586 & 54.8 & 17.8 & 665 & 267 \\
\hline 24 & Helegiu (Tazlău) & 998 & 0.004 & 0.009 & 2.64 & M & 1.6 & 1221 & 10.4 & 435 & 48.8 & 28.9 & 605 & 213 \\
\hline 25 & Ciuruc (Șușița) & 178 & 0.163 & 0.379 & 3.01 & M & 1.8 & 985 & 10.6 & 499 & 62.6 & 5.5 & 645 & 234 \\
\hline 26 & Tulnici (Putna) & 313 & 0.236 & 0.623 & 2.53 & $\mathrm{~F}$ & 1.0 & 1280 & 16.8 & 753 & 88.5 & 0.5 & 759 & 208 \\
\hline 27 & Nereju (Zăbala) & 263 & 6.091 & 20.430 & 2.83 & $\mathrm{~F}$ & 1.1 & 1253 & 14.8 & 714 & 84.3 & 4.7 & 781 & 210 \\
\hline 28 & Colacu (Putna) & 1087 & 2.435 & 7.749 & 2.87 & $\mathrm{~F}$ & 1.3 & 1508 & 14.9 & 719 & 71.0 & 4.8 & 735 & 164 \\
\hline 29 & Boțârlău (Putna) & 2450 & 1.511 & 4.608 & 3.00 & $P \& Q$ & 1.5 & 1755 & 10.3 & 506 & 51.3 & 32.5 & 642 & 117 \\
\hline 30 & Golești (Milcov) & 406 & 1.426 & 4.180 & 3.14 & M & 1.9 & 1219 & 10.3 & 472 & 55.8 & 26.0 & 595 & 55 \\
\hline 31 & Jiliște (Râmna) & 398 & 0.611 & 1.482 & 3.14 & $P \& Q$ & 1.9 & 860 & 7.5 & 325 & 36.9 & 36.4 & 570 & 42.6 \\
\hline 32 & Tulburea (Râmnicu Sărat) & 187 & 1.610 & 4.652 & 3.14 & M & 1.6 & 1033 & 14.5 & 650 & 65.1 & 10.4 & 709 & 268 \\
\hline 33 & Tătaru (Râmnicu Sărat) & 1048 & 0.659 & 1.727 & 2.95 & $P \& Q$ & 1.9 & 1375 & 5.1 & 242 & 26.1 & 51.0 & 569 & 76.2 \\
\hline 34 & Sita Buzău (Buzău) & 360 & 0.144 & 0.329 & 2.19 & $\mathrm{~F}$ & 1.0 & 1250 & 12.0 & 550 & 39.9 & 1.5 & 788 & 509 \\
\hline 35 & Potârnichești (Câlnău) & 194 & 0.423 & 1.036 & 3.14 & M & 1.9 & 627 & 7.7 & 313 & 17.6 & 51.4 & 585 & 63.8 \\
\hline 36 & Cernătești (Slănic) & 422 & 1.225 & 3.474 & 3.13 & M & 1.8 & 1210 & 12.0 & 521 & 35.6 & 25.1 & 661 & 103 \\
\hline 37 & Bâsca Rozilei (Bâsca) & 783 & 2.126 & 6.561 & 2.62 & $\mathrm{~F}$ & 1.0 & 1360 & 14.4 & 660 & 82.4 & 0.1 & 803 & 494 \\
\hline 38 & Varlaaam II (Bâsca Mică) & 239 & 3.339 & 10.435 & 2.72 & $\mathrm{~F}$ & 1.0 & 1211 & 14.6 & 701 & 84.1 & 0.0 & 824 & 466 \\
\hline
\end{tabular}


Table 5. Pearson correlation matrix for catchment sediment yield (SY) and various catchment characteristics (see Tables 3 and 4). 'In' indicates that the considered variable was logarithmically transformed. Values in italic are insignificant $(p>0.05)$, values in bold are significant $(p<0.05)$, and values in bold and underlined are highly significant $(p<0.0001)$.

\begin{tabular}{|c|c|c|c|c|c|c|c|c|c|c|c|c|c|c|c|c|c|c|c|c|c|c|c|}
\hline & $\varangle$ & 絪 & 苞 & 曾 & 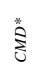 & 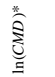 & 怘 & 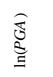 & $\sim$ & 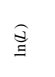 & $\approx$ & $\widehat{\overparen{\xi}}$ & $\frac{0}{0}$ & 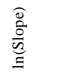 & ミ & & 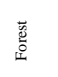 & ४ & 2 & E & $\approx$ & $\stackrel{8}{g}$ & 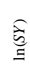 \\
\hline $\begin{array}{c}A \\
\ln (A)\end{array}$ & 0.89 & & & & & & & & & & & & & & & & & & & & & & \\
\hline$E D^{*}$ & $\frac{.0 .5}{-0.13}$ & -0.08 & & & & & & & & & & & & & & & & & & & & & \\
\hline $\ln (E D)^{*}$ & -0.12 & -0.03 & 0.74 & & & & & & & & & & & & & & & & & & & & \\
\hline$C M D^{*}$ & -0.13 & -0.08 & $\underline{1.00}$ & $\underline{0.71}$ & & & & & & & & & & & & & & & & & & & \\
\hline $\ln (C M D)^{*}$ & -0.09 & 0.01 & $\underline{0.73}$ & 0.99 & $\underline{0.70}$ & & & & & & & & & & & & & & & & & & \\
\hline$P G A$ & -0.04 & -0.06 & $\overline{0.48}$ & $\underline{0.79}$ & $\overline{0.45}$ & $\underline{0.76}$ & & & & & & & & & & & & & & & & & \\
\hline $\ln (P G A)$ & -0.03 & -0.08 & 0.45 & $\underline{0.72}$ & 0.42 & $\overline{0.69}$ & $\underline{0.99}$ & & & & & & & & & & & & & & & & \\
\hline L & 0.02 & -0.03 & 0.16 & 0.48 & 0.13 & $\overline{0.46}$ & $\underline{0.77}$ & $\underline{0.75}$ & & & & & & & & & & & & & & & \\
\hline $\ln (L)$ & 0.02 & -0.06 & 0.19 & 0.47 & 0.17 & 0.44 & $\underline{0.79}$ & $\underline{0.79}$ & $\underline{0.98}$ & & & & & & & & & & & & & & \\
\hline$R$ & $\underline{0.70}$ & $\underline{0.81}$ & 0.19 & 0.25 & 0.19 & 0.29 & $\overline{0.06}$ & $\overline{0.03}$ & $-\overline{0.17}$ & -0.18 & & & & & & & & & & & & & \\
\hline $\ln (R)$ & $\underline{0.63}$ & $\underline{0.78}$ & 0.20 & 0.26 & 0.20 & 0.30 & 0.07 & 0.03 & -0.17 & -0.18 & $\underline{0.99}$ & & & & & & & & & & & & \\
\hline Slope & $-\overline{-0.10}$ & $-\overline{-0.10}$ & 0.03 & -0.20 & 0.05 & -0.19 & -0.35 & -0.34 & -0.78 & -0.74 & $\overline{0.18}$ & 0.22 & & & & & & & & & & & \\
\hline $\ln$ (Slope) & -0.07 & -0.09 & 0.05 & -0.18 & 0.07 & -0.17 & -0.33 & -0.32 & $\underline{-0.75}$ & $\frac{-0.70}{0.70}$ & 0.19 & 0.22 & $\underline{0.99}$ & & & & & & & & & & \\
\hline$M L R$ & -0.02 & 0.02 & 0.19 & 0.00 & 0.21 & 0.02 & -0.23 & -0.23 & -0.71 & $\underline{-0.68}$ & 0.37 & 0.41 & $\overline{\underline{0.94}}$ & $\underline{0.94}$ & & & & & & & & & \\
\hline $\ln (M L R)$ & 0.00 & 0.01 & 0.17 & -0.02 & 0.19 & 0.00 & -0.23 & -0.23 & -0.70 & -0.66 & 0.35 & 0.40 & $\underline{0.94}$ & $\underline{0.96}$ & $\underline{0.99}$ & & & & & & & & \\
\hline Forest & -0.09 & -0.08 & 0.26 & 0.09 & 0.27 & 0.13 & -0.13 & -0.13 & $\overline{-0.45}$ & $\overline{-0.41}$ & 0.25 & 0.31 & $\overline{0.63}$ & $\overline{\underline{0.63}}$ & $\overline{0.72}$ & $\underline{0.71}$ & & & & & & & \\
\hline$A L$ & 0.17 & 0.21 & -0.10 & 0.06 & -0.11 & 0.05 & 0.26 & 0.24 & $\underline{0.70}$ & $\underline{0.64}$ & -0.14 & -0.18 & $\underline{-0.85}$ & $\underline{-0.88}$ & -0.85 & -0.87 & -0.70 & & & & & & \\
\hline$P$ & -0.05 & 0.03 & 0.14 & -0.14 & 0.16 & -0.12 & -0.53 & -0.55 & $\underline{-0.87}$ & $\frac{0.84}{-0.84}$ & 0.27 & 0.29 & $\underline{\underline{0.79}}$ & $\underline{0.79}$ & 0.79 & 0.78 & 0.50 & -0.78 & & & & & \\
\hline $\ln (P)$ & -0.05 & 0.03 & 0.13 & -0.15 & 0.15 & -0.13 & -0.53 & -0.54 & -0.88 & -0.83 & 0.27 & 0.29 & $\underline{0.80}$ & 0.80 & 0.80 & 0.80 & 0.51 & -0.79 & 1.00 & & & & \\
\hline Ro & 0.01 & 0.03 & -0.12 & -0.30 & -0.10 & -0.27 & -0.57 & -0.56 & -0.77 & -0.72 & 0.21 & 0.23 & $\underline{0.60}$ & $\underline{0.61}$ & 0.58 & $\underline{0.59}$ & 0.45 & $\frac{-0.69}{-0.9}$ & $\underline{\underline{0.85}}$ & $\underline{0.84}$ & & & \\
\hline $\ln (R o)$ & 0.05 & 0.02 & -0.14 & -0.42 & -0.12 & -0.39 & -0.60 & -0.57 & -0.79 & $\underline{-0.72}$ & 0.18 & 0.20 & $\overline{0.66}$ & $\overline{\underline{0.68}}$ & $\underline{0.63}$ & $\overline{0.65}$ & 0.49 & $\overline{-0.72}$ & $\overline{0.83}$ & $\overline{0.84}$ & $\underline{0.94}$ & & \\
\hline $\ln (S Y)$ & -0.05 & -0.05 & 0.54 & $\underline{0.75}$ & 0.51 & 0.72 & $\underline{\underline{0.86}}$ & $\underline{0.82}$ & $\underline{0.81}$ & $\underline{0.82}$ & 0.01 & 0.00 & $\overline{-0.48}$ & $\overline{-0.46}$ & .0 .36 & -0.36 & -0.23 & $\overline{0.46}$ & -0.57 & -0.57 & -0.63 & -0.68 & \\
\hline
\end{tabular}


Table 6. Fitted sediment rating curves for ten selected gauging stations, before and after the 1977 Earthquake (EQ). $V_{\mathrm{W} 2}$ indicates the contribution of the highest $2 \%$ of observed daily runoff discharges to the total runoff discharge of the considered period and reflects the importance of flood events in the total runoff discharge. $n$ indicates the number of observations. $\mathrm{a}$ and $\mathrm{b}$ are the coefficients of the rating curve (Eq. 1). $M E$ is the corresponding model efficiency (Nash and Sutcliffe, 1970). "Before EQ" lists the rating curves based on all observations made 5 years before the earthquake. "After EQ" lists the rating curves based on all observations respectively 1, 2 or 5 years after the earthquake. "After Eq fixed 'b"' lists the fitted rating curves based on the same observations, but using the exponent b as "Before EQ". For characteristics of the gauging stations and their corresponding catchments see Tables 2 and 4.

\begin{tabular}{|c|c|c|c|c|c|c|c|c|c|c|c|c|c|c|}
\hline & \multicolumn{5}{|c|}{ Before EQ } & & \multicolumn{5}{|c|}{ After EQ } & \multicolumn{3}{|c|}{ After EQ fixed 'b' } \\
\hline & $V \mathrm{w}_{2}$ & $n$ & $\mathrm{a}$ & $\mathrm{b}$ & $M E$ & & $V$ w2 & $n$ & $\mathrm{a}$ & $\mathrm{b}$ & $M E$ & $\mathrm{a}$ & $\mathrm{b}$ & $M E$ \\
\hline Golești & $33 \%$ & 1825 & 2.28 & 0.64 & 0.22 & $\begin{array}{l}1 \mathrm{yr} \\
2 \mathrm{yr} \\
5 \mathrm{yr}\end{array}$ & $\begin{array}{l}53 \% \\
40 \% \\
33 \%\end{array}$ & $\begin{array}{c}365 \\
730 \\
1825\end{array}$ & $\begin{array}{l}1.76 \\
2.04 \\
1.39\end{array}$ & $\begin{array}{l}0.79 \\
0.77 \\
0.86\end{array}$ & $\begin{array}{l}0.68 \\
0.38 \\
0.46\end{array}$ & $\begin{array}{l}3.16 \\
3.02 \\
2.63\end{array}$ & $\begin{array}{l}0.64 \\
0.64 \\
0.64\end{array}$ & $\begin{array}{l}0.64 \\
0.36 \\
0.40\end{array}$ \\
\hline Nereju & $22 \%$ & 1158 & 0.11 & 0.90 & 0.42 & $\begin{array}{l}1 \mathrm{yr} \\
2 \mathrm{yr} \\
5 \mathrm{yr}\end{array}$ & $\begin{array}{l}17 \% \\
18 \% \\
20 \%\end{array}$ & $\begin{array}{c}365 \\
730 \\
1825\end{array}$ & $\begin{array}{l}0.11 \\
0.12 \\
0.24\end{array}$ & $\begin{array}{l}1.23 \\
1.17 \\
0.94\end{array}$ & $\begin{array}{l}0.54 \\
0.45 \\
0.40\end{array}$ & $\begin{array}{l}0.38 \\
0.31 \\
0.27\end{array}$ & $\begin{array}{l}0.90 \\
0.90 \\
0.90\end{array}$ & $\begin{array}{l}0.44 \\
0.40 \\
0.40\end{array}$ \\
\hline Tulburea & $22 \%$ & 1824 & 1.47 & 0.86 & 0.24 & $\begin{array}{l}1 \mathrm{yr} \\
2 \mathrm{yr} \\
5 \mathrm{yr}\end{array}$ & $\begin{array}{l}22 \% \\
24 \% \\
23 \%\end{array}$ & $\begin{array}{c}364 \\
729 \\
1824\end{array}$ & $\begin{array}{l}1.92 \\
1.44 \\
1.17\end{array}$ & $\begin{array}{l}0.82 \\
0.78 \\
0.95\end{array}$ & $\begin{array}{l}0.40 \\
0.28 \\
0.29\end{array}$ & $\begin{array}{l}1.76 \\
1.20 \\
1.46\end{array}$ & $\begin{array}{l}0.86 \\
0.86 \\
0.86\end{array}$ & $\begin{array}{l}0.40 \\
0.27 \\
0.29\end{array}$ \\
\hline Jiliște & $38 \%$ & 1825 & 12.88 & 0.57 & 0.03 & $\begin{array}{l}1 \mathrm{yr} \\
2 \mathrm{yr} \\
5 \mathrm{yr}\end{array}$ & $\begin{array}{l}47 \% \\
44 \% \\
36 \%\end{array}$ & $\begin{array}{c}365 \\
730 \\
1825\end{array}$ & $\begin{array}{c}7.91 \\
10.28 \\
9.32\end{array}$ & $\begin{array}{l}0.65 \\
0.61 \\
0.59\end{array}$ & $\begin{array}{l}0.67 \\
0.66 \\
0.25\end{array}$ & $\begin{array}{c}9.42 \\
11.27 \\
9.74\end{array}$ & $\begin{array}{l}0.57 \\
0.57 \\
0.57\end{array}$ & $\begin{array}{l}0.65 \\
0.65 \\
0.25\end{array}$ \\
\hline Tulnici & $18 \%$ & 1825 & 0.06 & 0.83 & 0.36 & $\begin{array}{l}1 \mathrm{yr} \\
2 \mathrm{yr} \\
5 \mathrm{yr}\end{array}$ & $\begin{array}{l}17 \% \\
15 \% \\
18 \%\end{array}$ & $\begin{array}{c}365 \\
730 \\
1825\end{array}$ & $\begin{array}{l}0.07 \\
0.05 \\
0.02\end{array}$ & $\begin{array}{l}0.64 \\
0.85 \\
1.18\end{array}$ & $\begin{array}{l}0.11 \\
0.18 \\
0.39\end{array}$ & $\begin{array}{l}0.04 \\
0.05 \\
0.08\end{array}$ & $\begin{array}{l}0.83 \\
0.83 \\
0.83\end{array}$ & $\begin{array}{l}0.10 \\
0.18 \\
0.34\end{array}$ \\
\hline Ferăstrău & $20 \%$ & 1523 & 0.01 & 1.40 & 0.75 & $\begin{array}{l}1 \mathrm{yr} \\
2 \mathrm{yr} \\
5 \mathrm{yr}\end{array}$ & $\begin{array}{l}17 \% \\
14 \% \\
18 \%\end{array}$ & $\begin{array}{c}365 \\
730 \\
1824\end{array}$ & $\begin{array}{l}0.00 \\
0.01 \\
0.01\end{array}$ & $\begin{array}{l}1.76 \\
1.71 \\
1.40\end{array}$ & $\begin{array}{l}0.70 \\
0.67 \\
0.34\end{array}$ & $\begin{array}{l}0.02 \\
0.02 \\
0.01\end{array}$ & $\begin{array}{l}1.40 \\
1.40 \\
1.40\end{array}$ & $\begin{array}{l}0.65 \\
0.63 \\
0.34\end{array}$ \\
\hline Valea Uzului & $18 \%$ & 1825 & 0.03 & 0.85 & 0.24 & $\begin{array}{l}1 \mathrm{yr} \\
2 \mathrm{yr} \\
5 \mathrm{yr}\end{array}$ & $\begin{array}{l}15 \% \\
13 \% \\
13 \%\end{array}$ & $\begin{array}{c}365 \\
730 \\
1825\end{array}$ & $\begin{array}{l}0.07 \\
0.05 \\
0.04\end{array}$ & $\begin{array}{l}0.58 \\
0.76 \\
0.69\end{array}$ & $\begin{array}{l}0.02 \\
0.05 \\
0.05\end{array}$ & $\begin{array}{l}0.05 \\
0.04 \\
0.03\end{array}$ & $\begin{array}{l}0.85 \\
0.85 \\
0.85\end{array}$ & $\begin{array}{l}0.02 \\
0.05 \\
0.05\end{array}$ \\
\hline Ciuruc & $31 \%$ & 1825 & 0.42 & 0.85 & 0.25 & $\begin{array}{l}1 \mathrm{yr} \\
2 \mathrm{yr} \\
5 \mathrm{yr}\end{array}$ & $\begin{array}{l}48 \% \\
33 \% \\
29 \%\end{array}$ & $\begin{array}{c}365 \\
730 \\
1825\end{array}$ & $\begin{array}{l}0.81 \\
0.65 \\
0.38\end{array}$ & $\begin{array}{l}0.68 \\
0.72 \\
0.82\end{array}$ & $\begin{array}{l}0.39 \\
0.06 \\
0.09\end{array}$ & $\begin{array}{l}0.39 \\
0.40 \\
0.35\end{array}$ & $\begin{array}{l}0.85 \\
0.85 \\
0.85\end{array}$ & $\begin{array}{l}0.35 \\
0.06 \\
0.09\end{array}$ \\
\hline Dragoșa & $19 \%$ & 1825 & 0.01 & 1.35 & 0.31 & $\begin{array}{l}1 \mathrm{yr} \\
2 \mathrm{yr} \\
5 \mathrm{yr}\end{array}$ & $\begin{array}{l}13 \% \\
15 \% \\
17 \%\end{array}$ & $\begin{array}{c}365 \\
730 \\
1825\end{array}$ & $\begin{array}{l}0.05 \\
0.01 \\
0.01\end{array}$ & $\begin{array}{l}0.75 \\
1.27 \\
1.34\end{array}$ & $\begin{array}{l}0.22 \\
0.34 \\
0.25\end{array}$ & $\begin{array}{l}0.01 \\
0.01 \\
0.01\end{array}$ & $\begin{array}{l}1.35 \\
1.35 \\
1.35\end{array}$ & $\begin{array}{l}0.15 \\
0.34 \\
0.25\end{array}$ \\
\hline Brodina & $19 \%$ & 1825 & 0.05 & 0.87 & 0.16 & $\begin{array}{l}1 \mathrm{yr} \\
2 \mathrm{yr} \\
5 \mathrm{yr}\end{array}$ & $\begin{array}{l}16 \% \\
18 \% \\
17 \%\end{array}$ & $\begin{array}{c}365 \\
730 \\
1825\end{array}$ & $\begin{array}{l}0.19 \\
0.25 \\
0.15\end{array}$ & $\begin{array}{l}0.53 \\
0.54 \\
0.64\end{array}$ & $\begin{array}{l}0.12 \\
0.14 \\
0.15\end{array}$ & $\begin{array}{l}0.07 \\
0.09 \\
0.07\end{array}$ & $\begin{array}{l}0.87 \\
0.87 \\
0.87\end{array}$ & $\begin{array}{l}0.07 \\
0.08 \\
0.12\end{array}$ \\
\hline
\end{tabular}




\section{FIGURES}

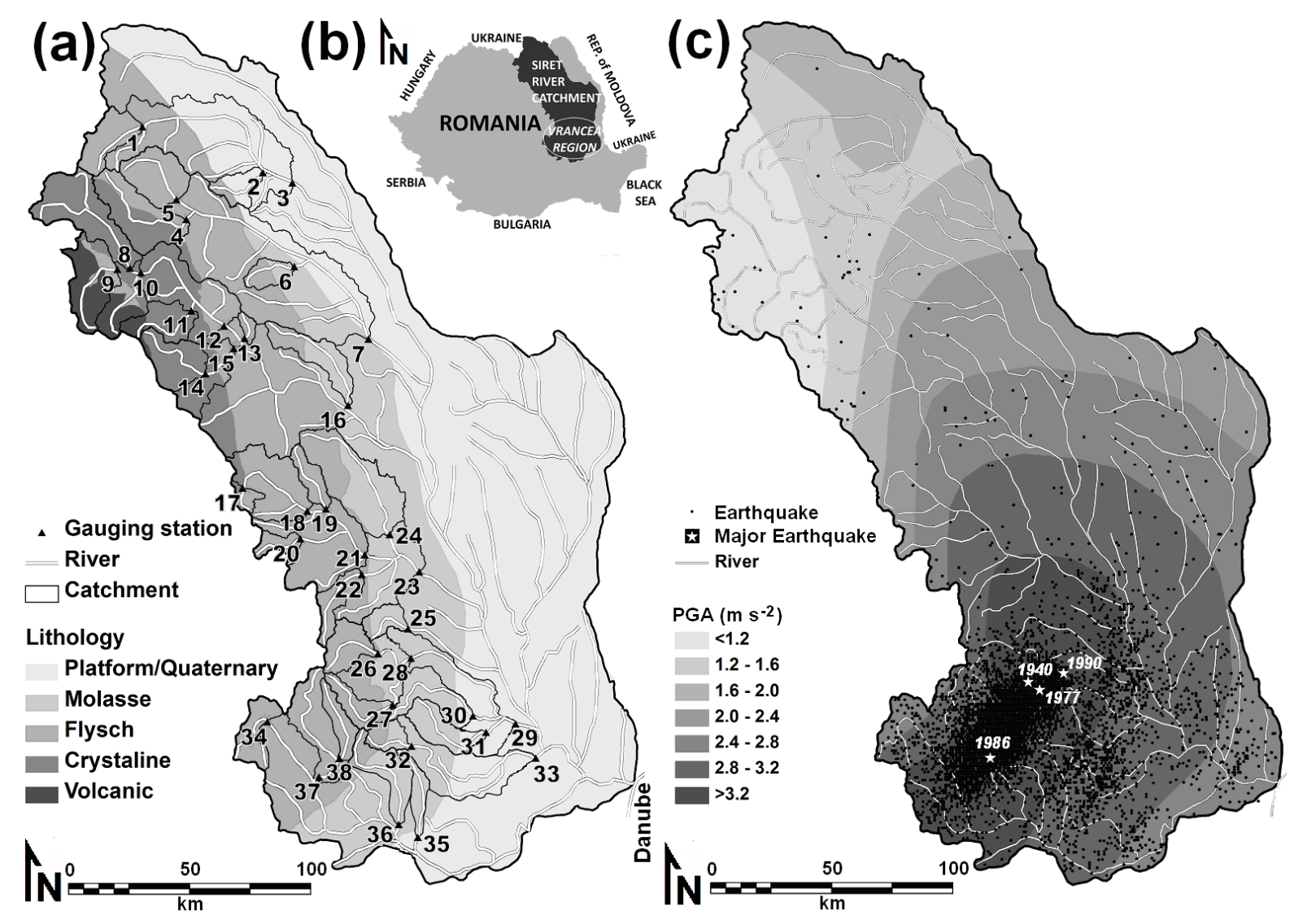

Fig. 1. Map of the study area. a) Subcatchments of the Siret basin $(n=38$, see also Tables 2 and 4) of which sediment yield observations were used in this study. Numbers correspond to those of Table 2. Grey shadings indicate major lithological units. b) Location of the Siret basin within Romania. c) Seismic activity in the Siret basin. Grey shadings indicate the expected peak ground acceleration (PGA) with a recurrence interval of 100 years (Lungu et al., 2004) Superimposed are all earthquakes with a magnitude $(M w)$ of 0.5 or higher, registered between 1900 and 2010. Stars and their corresponding years indicate the epicenters of major earthquakes indicated in Table 1. 
(a)

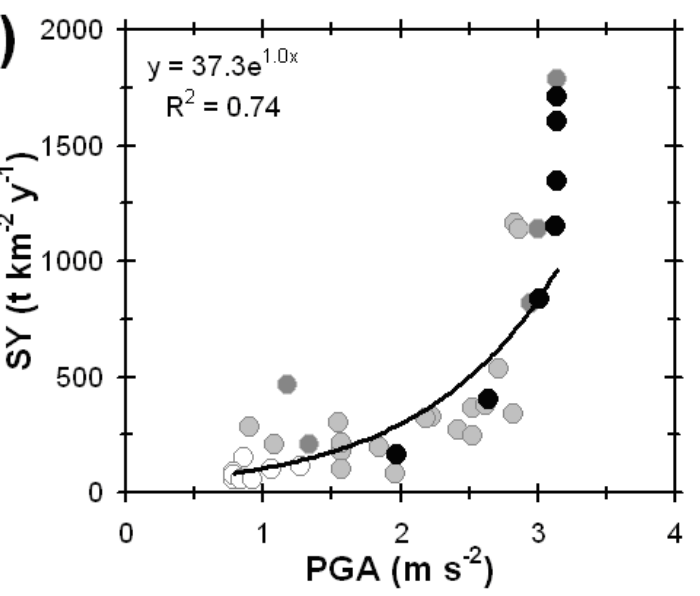

(c)

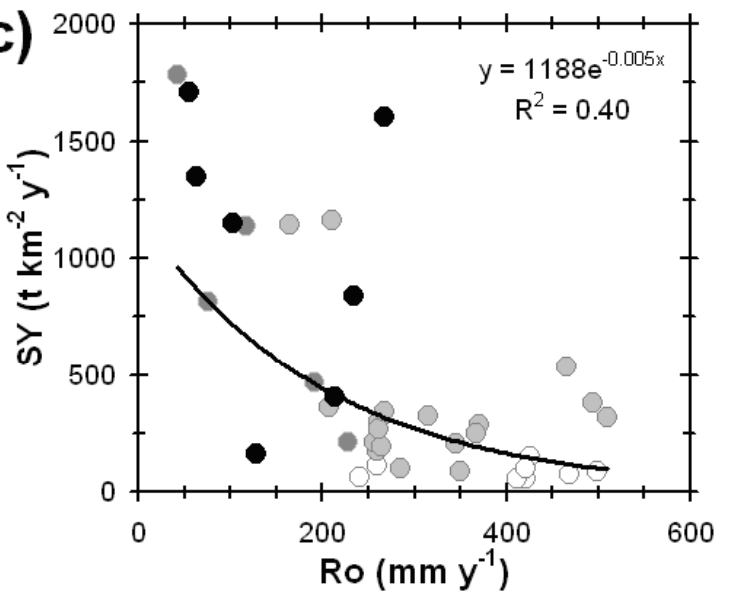

(e)

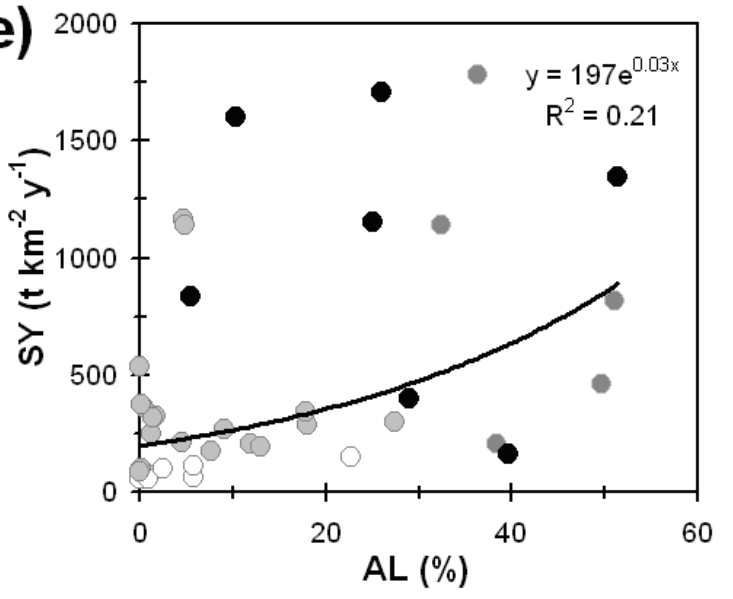

Volcanic and Crystalline $(n=8)$

Flysch $(\mathrm{n}=18)$

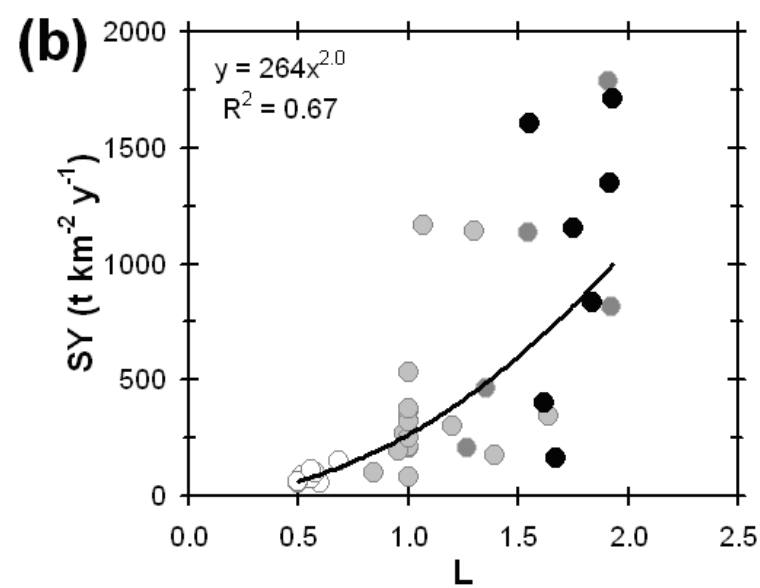

(d)

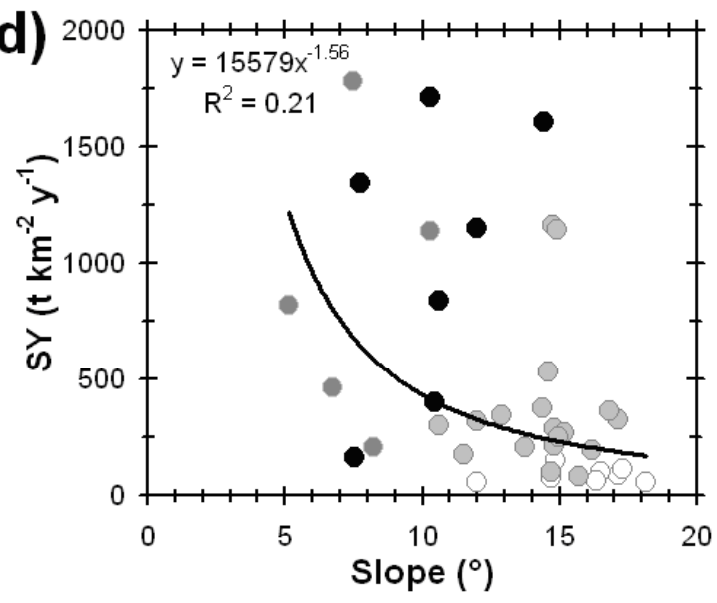

(f)

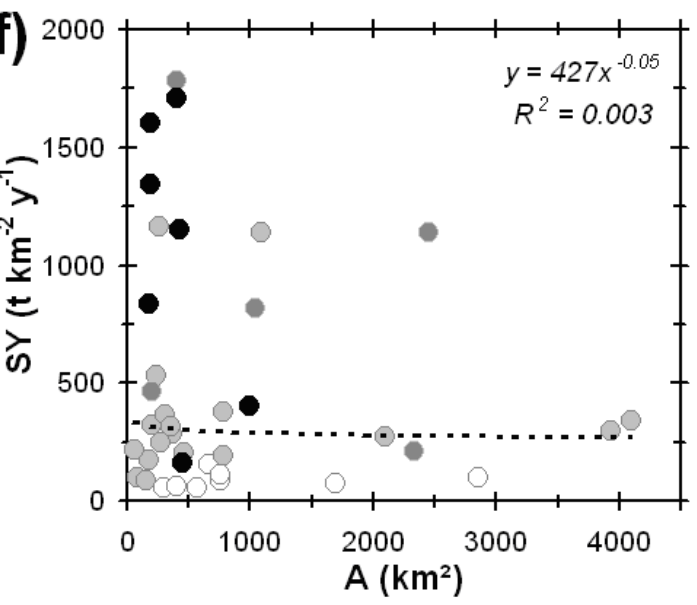

Platform and Quaternary $(n=5)$

- Molasse $(n=7)$

Fig. 2. Scatter plots of average catchment sediment yield $(S Y)$ and catchment characteristics (see Table 3). Symbols are shaded according to the dominant catchment lithology. Dashed regression line is insignificant $(p>0.05$; Table 5). $P G A=$ expected peak ground acceleration with a recurrence interval of 100 years; $L=$ lithology score; $R o=$ averaged measured runoff depth; Slope = average catchment Slope; $A L=$ percentage of arable land in 1990; $A=$ catchment area. 


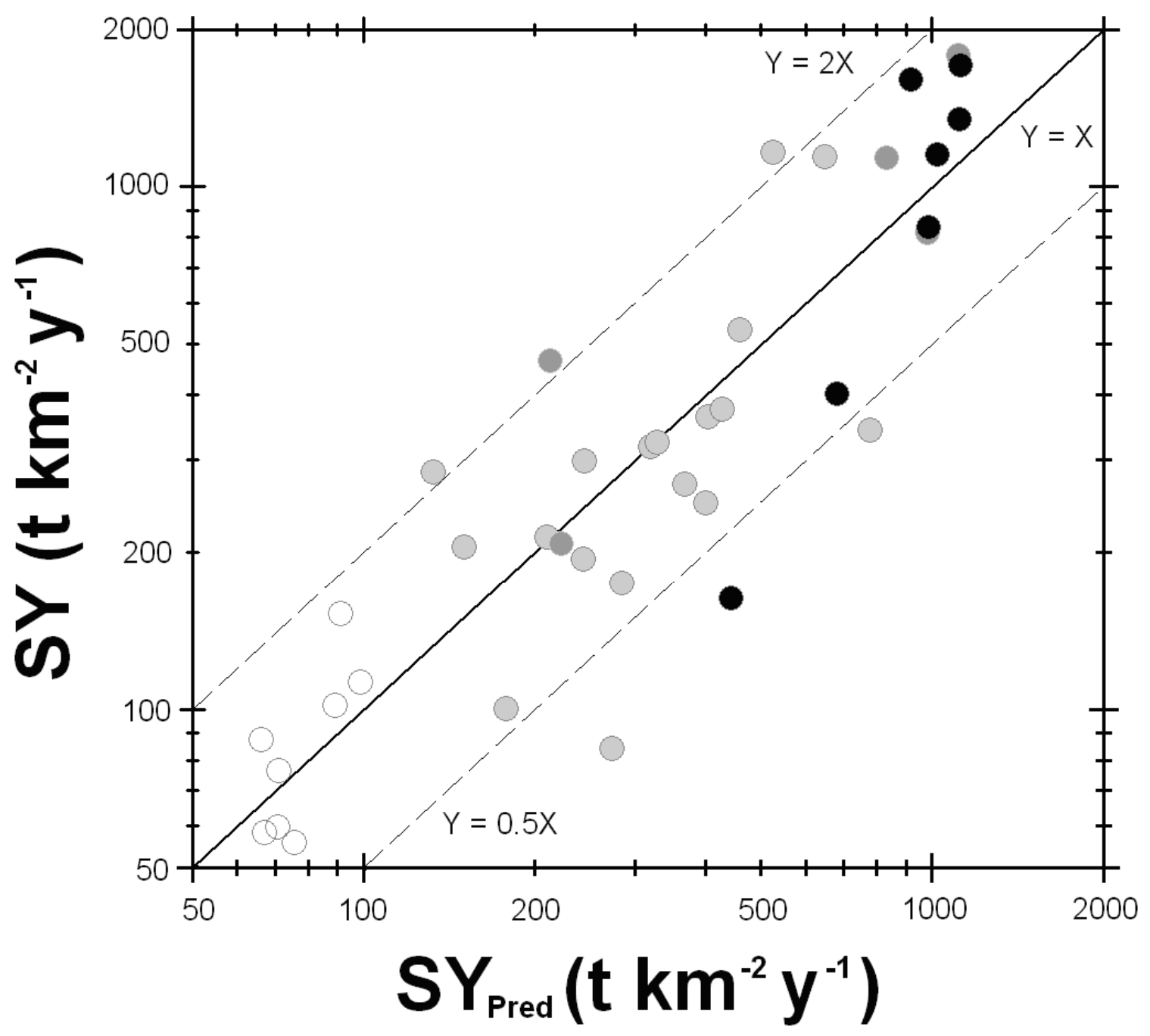

Volcanic and crystalline $(n=8)$

Flysch $(n=18)$

Platform and Quaternary $(n=5)$

- Molasse $(n=7)$

Fig. 3. Comparison between observed catchment sediment yield $(S Y)$ and sediment yield, predicted with Eq. (3) ( $S Y_{\text {pred }}$ ) for the 38 selected subcatchments (Tables 2 and 4). Symbols are shaded according to the dominant catchment lithology. 

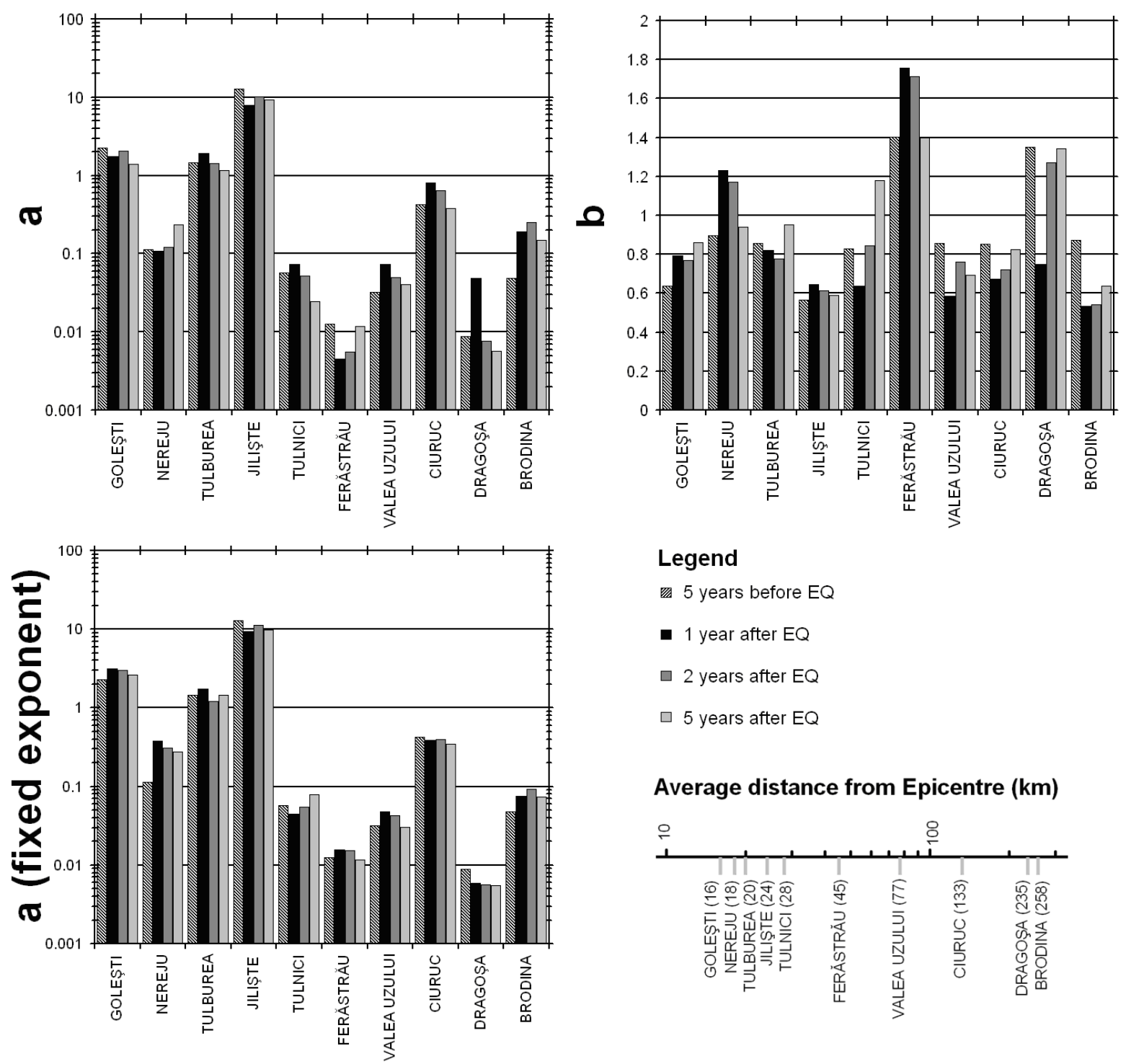

Legend

5 years before $\mathrm{EQ}$

- 1 year after $E Q$

$\square 2$ years after $E Q$

$\square 5$ years after $E Q$

\section{Average distance from Epicentre (km)}

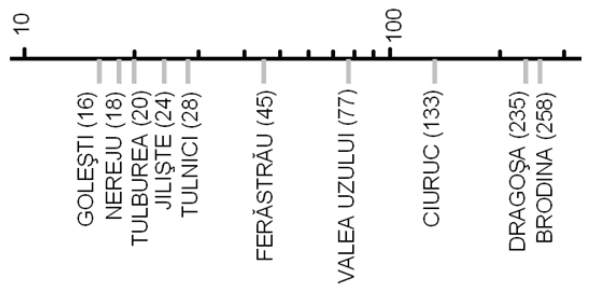

Fig. 4. Evolution of the coefficient a and exponent $b$ of the sediment rating curves (Eq. 1) for the indicated period before and after the 1977 earthquake (EQ). The lower histogram shows the evolution of the coefficient a for rating curves where the exponent $b$ was kept constant (i.e. the fitted b-exponent, based on the data 5 years before the EQ). See Table 6 for values. 

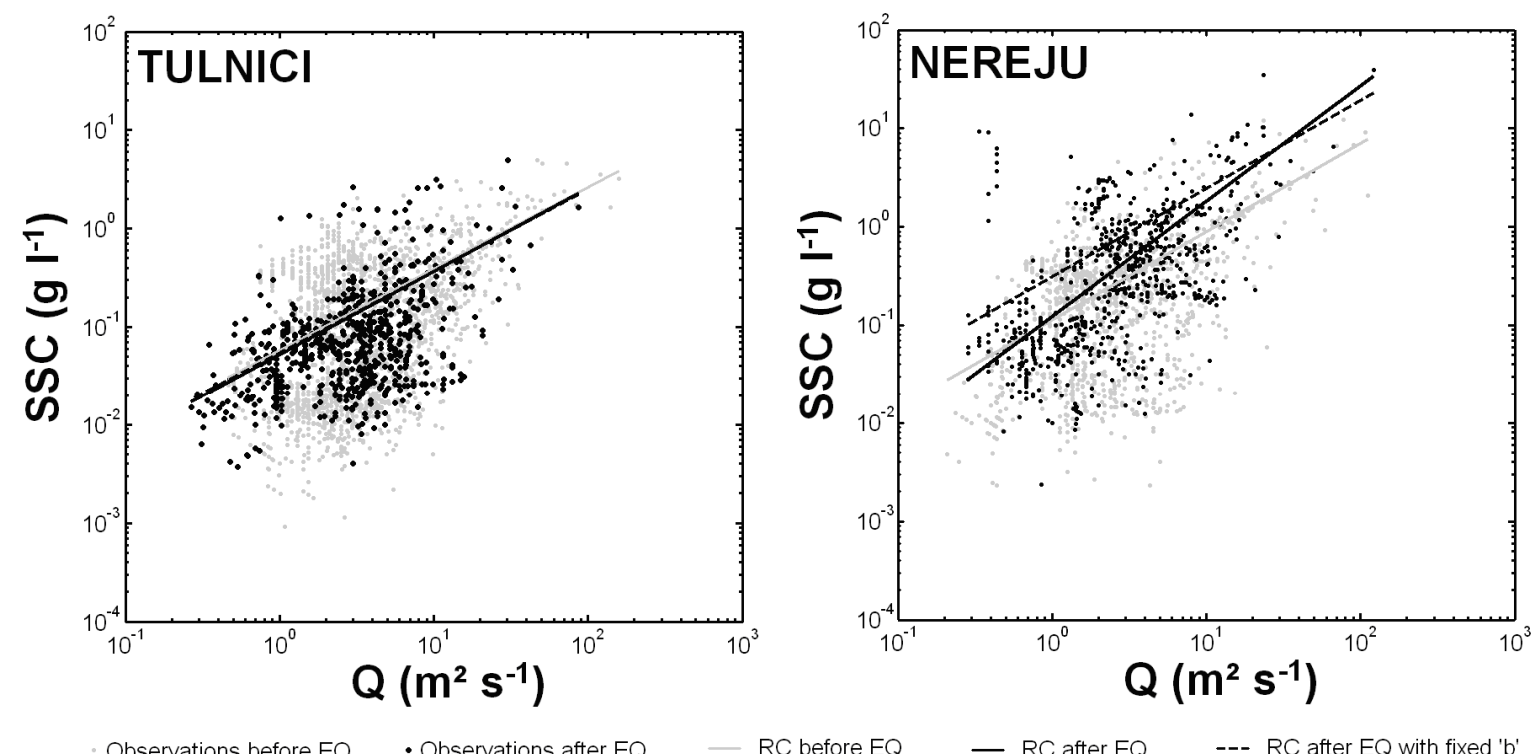

Observations before $\mathrm{EQ} \quad \cdot$ Observations after $\mathrm{EQ} \quad-\mathrm{RC}$ before $\mathrm{EQ} \quad-\mathrm{RC}$ after $\mathrm{EQ} \quad$--- $\mathrm{RC}$ after $\mathrm{EQ}$ with fixed ' $\mathrm{b}$ '

Fig. 5. Two examples of rating curves (RC), based on observations of runoff discharge $(Q)$ and sediment concentration (SSC) five years before and two years after the 1977 earthquake (EQ). See Table 6 for details on the rating curves. 


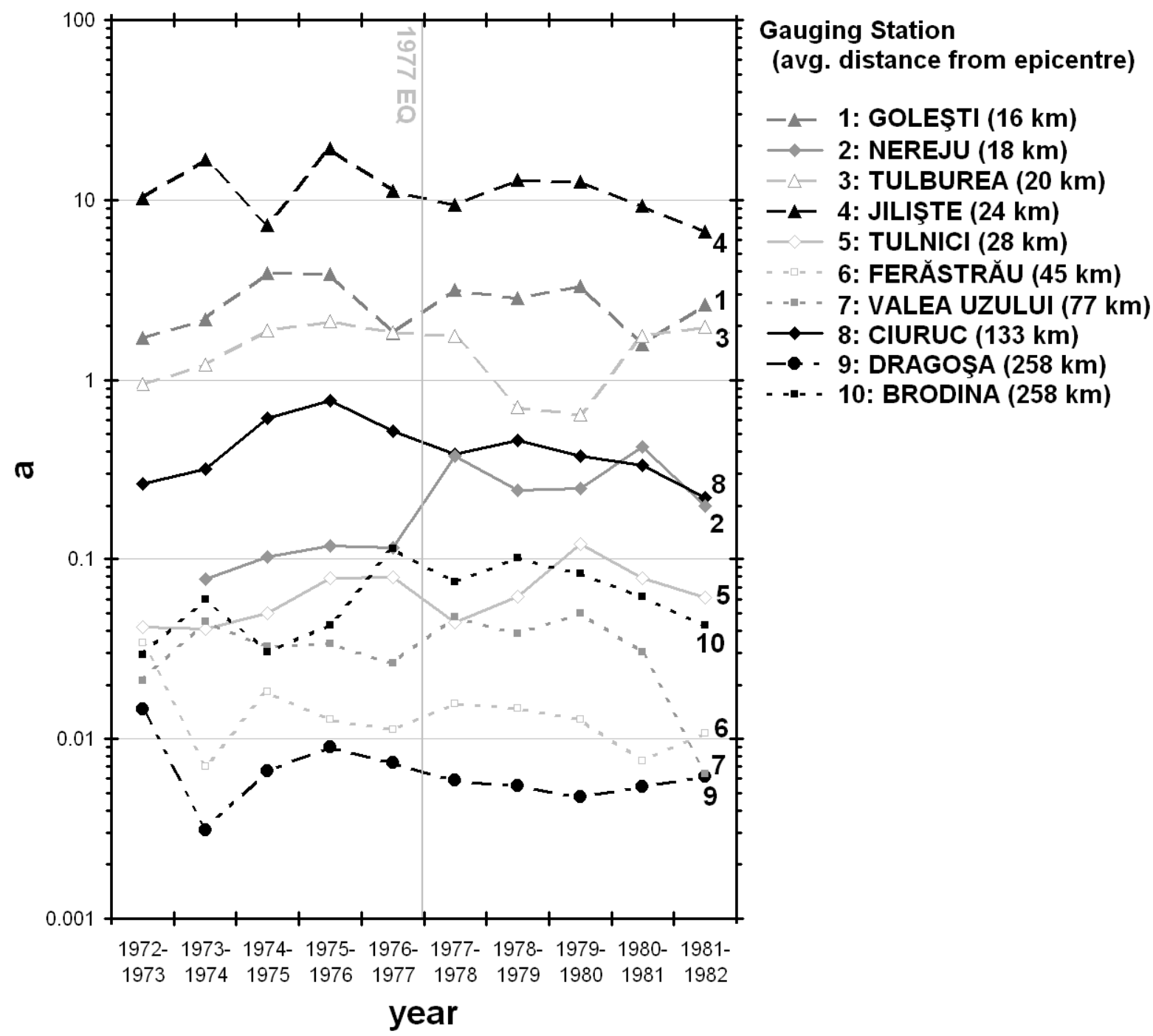

Fig. 6. Trends in the coefficient a of rating curves (Eq. 1) during the 5 years before and after the 7.4 Mw earthquake of 4 March 1977 for the ten selected subcatchments. Each coefficient a was fitted using a fixed exponent $b$ value based on all observations made during the five years before the earthquake (see Section 3.3 and Table 6) and by considering all daily runoff and sediment concentration observations made between 4th of March of the indicated year and 4th of March of the next year. 

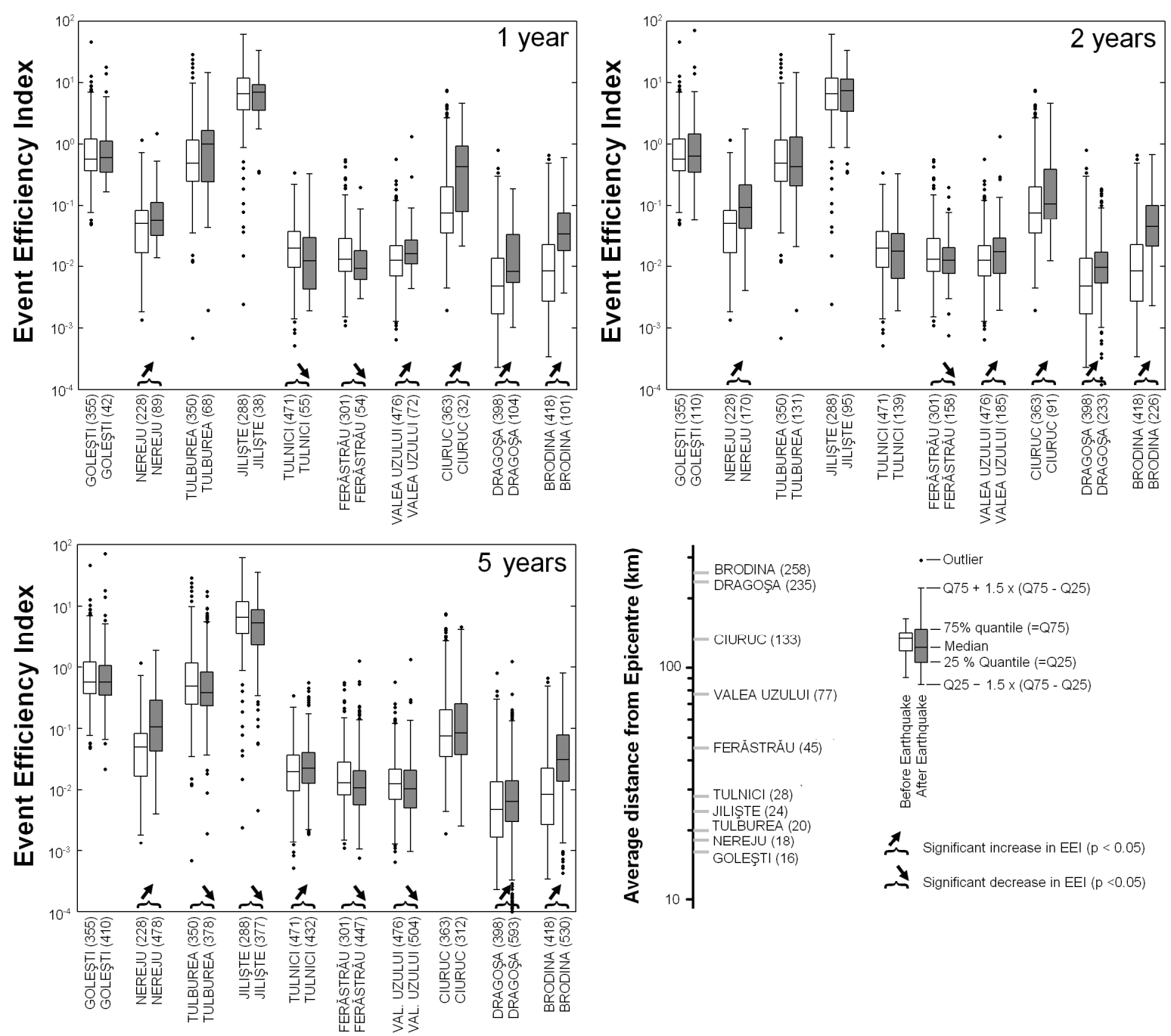

Fig. 7. Changes in the event efficiency index (EEI; Eq. 2) before and after the $7.4 \mathrm{Mw}$ earthquake of 1977. EEI values before the earthquake were calculated for all flood events (i.e. when runoff discharge exceeded 1.25 times the long-term average discharge) during the 5 years before the earthquake. EEI values after the earthquake where calculated for all flood events, respectively 1, 2 or 5 years after the earthquake. Stations are ordered according to the average distance of the catchment from the epicentre. Accolades indicate a significant (the Wilcoxon test; $p<0.05)$ increase or decrease in EEI before and after the earthquake. The number between brackets after the station name indicates the number of EEI values included in the boxplot. 


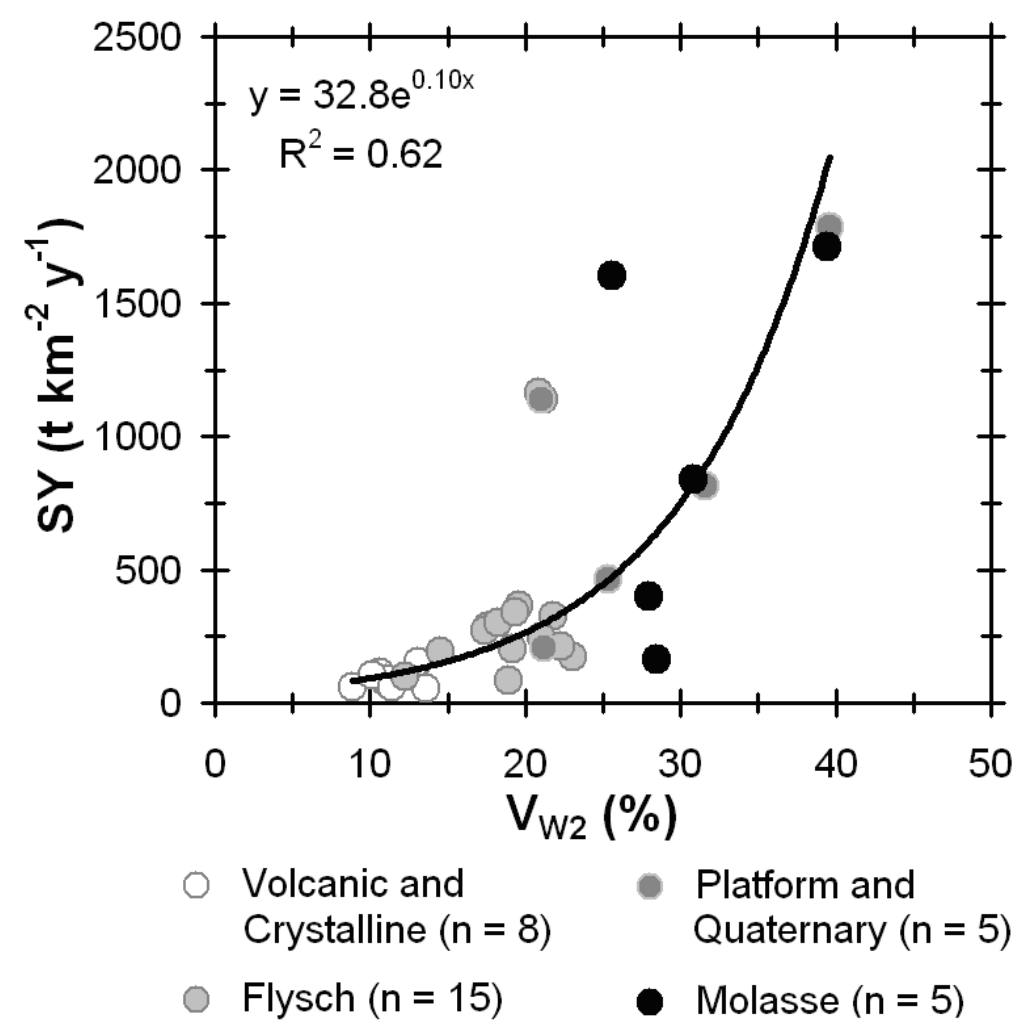

Fig. 8. Correlation between observed sediment yield $(S Y)$ and total percentage of water discharged during flood events, i.e. daily runoff discharge observations with an exceedance probability of $2 \%\left(V_{\mathrm{W} 2}\right)$ within the observation period. Stations for which no daily runoff discharge were available are excluded from this graph (i.e. stations 34-38, see Tables 2 and 4). 